\title{
Stratosphere-troposphere ozone exchange from high resolution MLS ozone analyses
}

\author{
J. Barré ${ }^{1}$, V.-H. Peuch ${ }^{2}$, J.-L. Attié ${ }^{1,3}$, L. El Amraoui ${ }^{1}$, W. A. Lahoz ${ }^{1,4}$, B. Josse ${ }^{1}$, M. Claeyman ${ }^{1,3}$, and P. Nédélec ${ }^{3}$ \\ ${ }^{1}$ CNRM-GAME, Météo-France and CNRS URA1357, Toulouse, France \\ ${ }^{2}$ ECMWF, Shinfield Park, Reading, UK \\ ${ }^{3}$ Laboratoire d'Aérologie, Université de Toulouse, CNRS/INSU, Toulouse, France \\ ${ }^{4}$ NILU, 2027 Kjeller, Norway
}

Correspondence to: J. Barré (jerome.barre@ meteo.fr)

Received: 8 November 2011 - Published in Atmos. Chem. Phys. Discuss.: 19 December 2011

Revised: 11 June 2012 - Accepted: 29 June 2012 - Published: 16 July 2012

Abstract. We assimilate stratospheric ozone profiles from MLS (Microwave Limb Sounder) into the MOCAGE Chemistry Transport Model (CTM) to study StratosphereTroposphere Exchange (STE). This study uses two horizontal grid resolutions of $2^{\circ}$ and $0.2^{\circ}$. The combined impacts of MLS ozone assimilation and high horizontal resolution are illustrated in two case studies where STE events occurred (23 June 2009 and 17 July 2009). At high resolution the filamentary structures of stratospheric air which characterise STE events are captured by the model. To test the impact of the assimilation and the resolution, we compare model outputs from different experiments (high resolution and low resolution; MLS assimilation run and free run) with independent data (MOZAIC aircraft ozone data; WOUDC ozone sonde network data). MLS ozone analyses show a better description of the Upper Troposphere Lower Stratosphere (UTLS) region and the stratospheric intrusions than the free model run. In particular, at high horizontal resolution the MLS ozone analyses present realistic filamentary ozone structures in the UTLS and laminae structures in the ozone profile. Despite a low aspect ratio between horizontal resolution and vertical resolution in the UTLS at high horizontal resolution, MLS ozone analyses improve the vertical structures of the ozone fields. Results from backward trajectories and ozone forecasts show that assimilation at high horizontal resolution of MLS ozone profiles between $10 \mathrm{hPa}$ and $215 \mathrm{hPa}$ has an impact on tropospheric ozone.

\section{Introduction}

In the stratosphere, ozone $\left(\mathrm{O}_{3}\right)$ is known to shield the surface from harmful ultraviolet radiation. In the middle and high troposphere ozone is the third most important greenhouse gas after carbon dioxide $\left(\mathrm{CO}_{2}\right)$ and methane $\left(\mathrm{CH}_{4}\right)$. Its forcing is equivalent to about $24 \%$ of that from carbon dioxide (Ramaswamy et al., 2001). The troposphere and stratosphere are characterised by different dynamical and chemical properties, with strong gradients of potential vorticity (PV) and ozone at the tropopause (Holton et al., 1995). Stratospheretroposphere exchange (STE) events play a key role in controlling the ozone budget in the Upper Troposphere Lower Stratosphere (UTLS), which in turn affects the radiation budget (IPCC 1996). The stratosphere is characterised by high values of $\mathrm{PV}$ and ozone concentrations, so intrusion of stratospheric air is expected to bring PV and ozone rich air into the troposphere. These intrusions typically form filamentary structures (Holton et al., 1995), which appear as laminae in the ozone profiles (Stohl et al., 2003) and often exhibit mesoscale features. Filamentary structures of PV and ozone at lower stratosphere have been simulated by Hauchecorne et al. (2002), Marchand et al. (2003) and Tripathi et al. (2006); these papers show that high resolution simulations are needed for detailed investigation of STE.

In the lower stratosphere, PV and ozone are nearly conserved on the synoptic time scale (Appenzeller et al., 1996). In addition, Beekmann et al. (1994) have shown that ozone fields and PV fields are strongly correlated in the UTLS layers of the atmosphere. Ozone fields in the UTLS region 
have strong vertical gradients. The representation of these gradients is a well-known limitation of most of the chemical transport models (CTM) as described by Law et al. (2000). Ozone measurements from the Microwave Limb Sounder (MLS) instrument on-board the Aura satellite give global coverage, and are able to detect stratospheric profiles between $215 \mathrm{hPa}$ and $0.46 \mathrm{hPa}$. Comparisons of simulated ozone fields with MLS ozone observations show good agreement in the UTLS spatial structure (Leblanc et al., 2006) and suggest that stratospheric intrusions can be captured by MLS. Due to the sparse horizontal sampling of these profiles, MLS ozone products are not able to resolve synoptic-scale variability in the tropopause region. To address this issue we use data assimilation which combines observational information with a priori information from a model in an objective way (Kalnay, 2003). Data assimilation of stratospheric ozone profiles from satellite data has been used extensively to study the UTLS distribution of ozone (Semane et al., 2007; El Amraoui et al., 2010; Wargan et al., 2010). These studies show that ozone analyses from assimilation of limb sounder ozone data can capture the signature of stratospheric intrusions in a realistic way.

In this paper we use the MOCAGE-PALM system of Météo-France to assimilate MLS ozone data into the MOCAGE (MOdèle de Chimie Atmospherique à Grande Echelle) CTM (Peuch et al., 1999). The aim is to have a better representation of the STE by increasing the horizontal grid model resolution from $2^{\circ}$ to $0.2^{\circ}$. In addition, we improve the representation of the STE by assimilating MLS ozone data. In order to investigate STE in detail, two typical cases studies are presented and validated with independent aircraft and balloon data. Finally, we show the impact of MLS analyses on tropospheric ozone using backward trajectories and ozone forecasts. The outline of the paper is as follows: Section 2 describes the MOCAGE CTM and the assimilation method. Section 3 presents the impact of MLS ozone assimilation on the MOCAGE model. In Sect. 4, results of two case studies of STE are presented. The validation with independent data is discussed. Before concluding in Sect. 6, we discuss in Sect. 5 the impact of model high resolution and MLS ozone assimilation on tropospheric ozone.

\section{Methodology}

\subsection{CTM model}

The MOCAGE model is a three-dimensional CTM for the troposphere and the stratosphere (Peuch et al., 1999) which simulates the interactions between the physical and chemical processes. It uses a semi-Lagrangian advection scheme (Josse et al., 2004) to transport the chemical species. It has 47 hybrid levels from the surface to $\sim 5 \mathrm{hPa}$ with a vertical resolution of about $150 \mathrm{~m}$ in the lower troposphere increasing to $800 \mathrm{~m}$ in the higher troposphere. Turbulent diffusion is cal- culated with the scheme of Louis (1979) and convective processes with the scheme of Bechtold et al. (2001). The chemical scheme used in this study is RACMOBUS. It is a combination of the stratospheric scheme REPROBUS (Lefèvre et al., 1994) and the tropospheric scheme RACM (Stockwell et al., 1997). It includes 119 individual species with 89 prognostic variables and 372 chemical reactions. MOCAGE has the flexibility to be used for both stratospheric studies (El Amraoui et al., 2008a) and tropospheric studies (Dufour et al., 2005). It is used in the operational air quality monitoring system in France, Prev'air (Rouil et al., 2008), and in the pre-operational GMES (Global Monitoring for Environment and Security) atmospheric core service (Hollingsworth et al., 2008). A detailed validation of the model has been done using a large number of measurements during the Intercontinental Transport of Ozone and Precursors (ICARTT/ITOP) campaign (Bousserez et al., 2007). The meteorological analyses of Météo-France, ARPEGE (Courtier et al., 1991) are used to force the dynamics of the model every $3 \mathrm{~h}$. To force the model, ARPEGE analyses are interpolated onto the MOCAGE grid. The resolution of ARPEGE analyses is T798 (i.e. resolution from $10.5 \mathrm{~km}$ over France to $60 \mathrm{~km}$ over the South Pacific). MOCAGE can be used in tracer mode and to specify the temporal and geometrical characteristics of a tracer release. An additional capability of MOCAGE is the calculation of backwards 3-D simulations, using the MOCAGE adjoint.

In this study, we use 2 domains: a global domain at $2^{\circ}$ (low horizontal resolution: LR) and a regional nested domain at $0.2^{\circ}$ (high horizontal resolution: HR) over Europe, from $32^{\circ} \mathrm{N}$ to $72^{\circ} \mathrm{N}$ and from $16^{\circ} \mathrm{W}$ to $36^{\circ} \mathrm{E}$. Four modelling experiments are performed:

1. low resolution free model run,

2. low resolution MLS ozone analysis,

3. high resolution free model run,

4. high resolution MLS ozone analysis.

The forcing fields differ because of the interpolation from the ARPEGE fields. For the low resolution the interpolation effect is important but for the high resolution the interpolation effect should be negligible because the ARPEGE resolution over Europe is in the range of the resolution of the MOCAGE model at the high resolution (around 10-20 km). Pisso et al. (2009) has shown that a vertical resolution of the order of $500 \mathrm{~m}$ and at least $40 \mathrm{~km}$ of horizontal resolution are needed to accurately simulate the transport of pollutants (carbon monoxide for this case study) in the free troposphere. Thus, the aspect ratio of the tracer between horizontal and vertical scales should be in the order of 100 . In this study the aspect ratio is about 25 and suggests that the vertical resolution is underestimated compared to the horizontal resolution. However we show, in the comparisons using independent data (Sects. 4.2.4 and 4.3.4), that our model with this 
aspect ratio gives realistic results. The simulations in this paper cover the period from 1 June 2009 to 1 September 2009. The assimilation experiment started on 1 June 2009. The initialisation field for this date has been obtained from a free model run started from the April climatological initial field. We thus have a free model run spin-up of 2 month before the 1 June 2009.

\subsection{Data assimilation system}

The assimilation system used in this study is MOCAGEPALM implemented within the PALM framework (Buis et al., 2006). The technique used is 3D-FGAT (First Guess at Appropriate Time, Fisher and Andersson, 2001). This technique is a compromise between the 3D-Var (3-D-variational) and the 4D-Var (4-D-variational) methods. 3D-FGAT provides time information for a sequence of observations as in the 4D-Var technique. The advantage of this technique is a lower numerical cost without the need to code a full adjoint model as needed for the 4D-Var technique. The choice of this technique limits the size of the assimilation window, since it has to be short enough compared to the chemistry and transport timescales. It has been validated during the assimilation of ENVISAT data project (ASSET, Lahoz et al., 2007) and has produced good quality results compared to independent data and other assimilation systems (Geer et al., 2006). MOCAGE-PALM has been used to assess the quality of satellite ozone measurements (Massart et al., 2007). Assimilation products have been used in many atmospheric studies in relation to ozone loss in the Arctic vortex (El Amraoui et al., 2008a), tropics-mid-latitudes exchange (Bencherif et al., 2007), STE (Semane et al., 2007), exchange between the polar vortex and the mid-latitudes (El Amraoui et al., 2008b), and diagnosing STE from ozone and carbon monoxide fields (El Amraoui et al., 2010).

\subsection{Aura/MLS ozone observations}

The Aura satellite was launched on 15 July 2004 and placed into a near-polar Earth orbit at $\sim 705 \mathrm{~km}$ with an inclination of $98^{\circ}$ and an ascending node at 13:45 UT. It makes about 14 orbits per day. The MLS instrument on-board Aura uses the microwave limb sounding technique to measure chemical constituents and dynamical tracers between the upper troposphere and the lower mesosphere (Waters et al., 2006). It provides dense spatial coverage with 3500 profiles daily between $82^{\circ} \mathrm{N}$ and $82^{\circ} \mathrm{S}$. In this study we use the Version 2.2 of the MLS O 3 dataset. It is a retrieval between $215 \mathrm{hPa}$ and $0.46 \mathrm{hPa}$ with a vertical resolution of $3 \mathrm{~km}$ in the upper troposphere and the stratosphere. For ozone measurements the along-track resolution is $\sim 200 \mathrm{~km}$ and the cross-track resolution is $\sim 6 \mathrm{~km}$ between 215 and $10 \mathrm{hPa}$. The estimated single profile precision in the extratropical UTLS region is of the order of $0.04 \mathrm{ppmv}$ (parts per million by volume) from $215 \mathrm{hPa}$ to $100 \mathrm{hPa}$ and between
$0.05 \mathrm{ppmv}$ and $0.2 \mathrm{ppmv}$ from $46 \mathrm{hPa}$ to $10 \mathrm{hPa}$ (Froidevaux et al., 2008). For the assimilation experiments, MLS data are selected according to the precision and quality flags recommended in the MLS Version 2.2 Level data quality and description document (see http://mls.jpl.nasa.gov/data/ v2-2_data_quality_document.pdf). The errors for each profile are taken into account in the assimilation process through the error covariance matrix of the observations. Only measurements made between $215 \mathrm{hPa}$ and $10 \mathrm{hPa}$ are used during the assimilation experiment because of the limitation imposed by the upper boundary $(5 \mathrm{hPa})$ of the MOCAGE version used in this paper.

\section{MLS assimilation}

In this section, we show the impact of MLS ozone data assimilation on the MOCAGE model. Assimilation increments, (i.e. the difference between the first guess fields and the analysis, in the assimilation window time step) increase the ozone concentrations at middle and polar latitudes in the lower stratosphere. Figure 1a shows mean increments of MLS ozone assimilation for July 2009, zonally averaged over Europe as a percentage of the ratio increments/free run for the HR runs. MLS ozone profiles are between $10 \mathrm{hPa}$ and $215 \mathrm{hPa}$, thus the increment is only located at these levels. The largest increments are located between $200 \mathrm{hPa}$ and $300 \mathrm{hPa}$ and $45^{\circ} \mathrm{N}$ and $72^{\circ} \mathrm{N}$. Figure $1 \mathrm{~b}$ also shows relative difference in $\%$ between the free run field and the MLS ozone analysis field, zonally averaged over Europe for July 2009 (i.e. ([free run]-[MLS analysis])/[free run]). Comparison between the relative differences and the assimilation increments, shows major differences to be located in the same region: between $200 \mathrm{hPa}$ and $300 \mathrm{hPa}$ and $45^{\circ} \mathrm{N}$ and $70^{\circ} \mathrm{N}$. In figure 1, positive differences with values around $20 \%$ between $1000 \mathrm{hPa}$ and $300 \mathrm{hPa}$ and $40^{\circ} \mathrm{N}$ and $72^{\circ} \mathrm{N}$ which are visible in the relative differences do not occur in the assimilation increments. This impact observed in the troposphere is the result of the southward cross-tropopause advection of lower stratospheric air masses which have higher ozone values owing to assimilation.

Figure 2 presents zonal means of ozone over the Northern Hemisphere for July 2009, for the free model run (Fig. 2a) and the MLS ozone analyses (Fig. 2b) for LR runs. Black lines delineate the potential temperature iso-lines, the white lines delineate the $2 \mathrm{PVU}$ iso-lines $(1 \mathrm{PVU}=1 \times$ $10^{6} \mathrm{~K} \mathrm{~kg}^{-1} \mathrm{~m}^{2} \mathrm{~s}^{-1}$ ). For the mid and polar latitudes, stratospheric ozone rich air is located above $350 \mathrm{~K}$. In the stratosphere MLS ozone analysis values are higher than the free run values for levels located between $330 \mathrm{~K}$ and $370 \mathrm{~K}$. Isentropic lines (i.e. potential temperature lines) between $320 \mathrm{~K}$ and $340 \mathrm{~K}$ cross the $2 \mathrm{PVU}$ iso-lines (the 2-PVU isoline identifies the dynamical tropopause), and tilt downward between $300 \mathrm{hPa}$ and $600 \mathrm{hPa}$ at mid-latitudes. The isentropic lines give an idea of the mean isentropic transport during July 

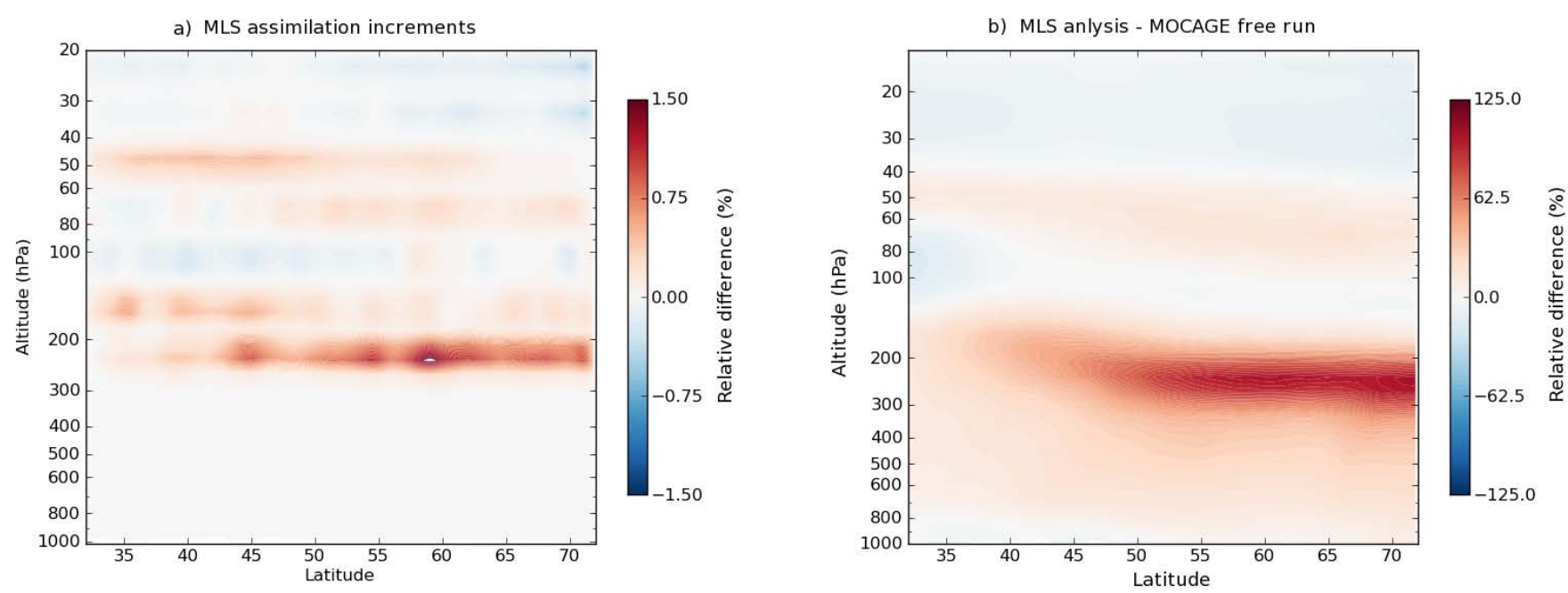

Fig. 1. (a) Zonal means of increments of MLS ozone analyses at high horizontal resolution $\left(0.2^{\circ}\right)$ in relative difference in \%; (b) Zonal means of the MLS ozone analysis minus the associated equivalent MOCAGE free run at high horizontal resolution $\left(0.2^{\circ}\right)$ in relative difference in $\%$. Zonal means are performed for the month of July 2009 over Europe.

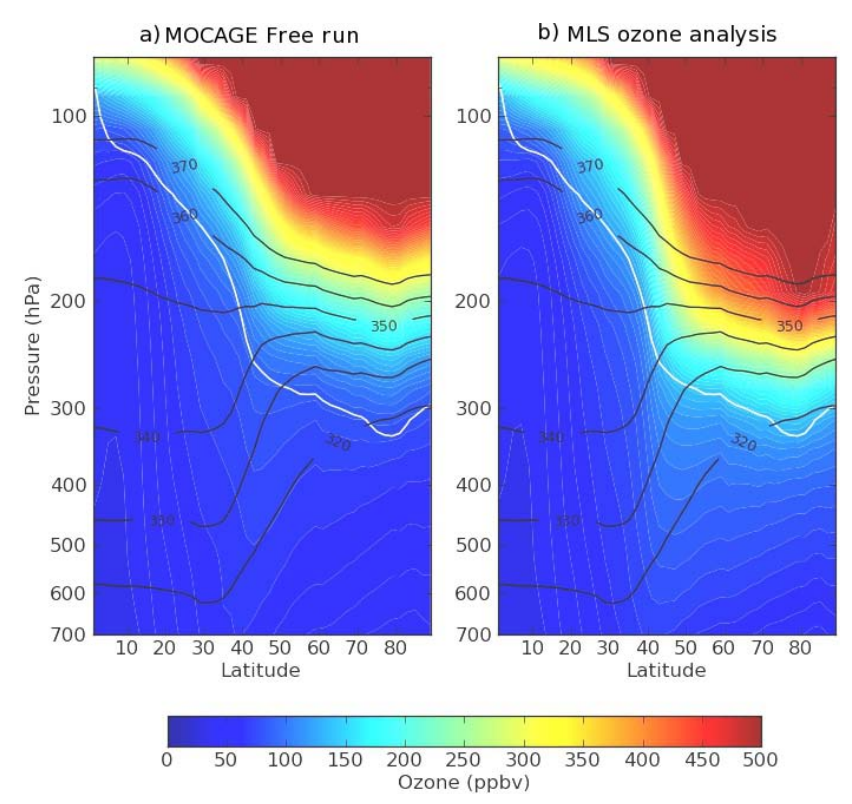

Fig. 2. Zonal means of ozone for the month of July 2009 in Northern Hemisphere (low resolution runs $2^{\circ}$ ). (a) MOCAGE free run, (b) MLS ozone analysis. Black lines are the potential temperature, the white line represents the $2 \mathrm{PVU}$ iso-line (an estimate of the tropopause height).

2009. In a general manner, most of the STEs are considered as an irreversible isentropic event in the lowermost stratosphere, where the isentropes cross the tropopause (Postel and Hitchman, 1999). Subsequent southward cross-tropopause advection of these increments during a STE event increases ozone concentrations in the analyses at the location of the intrusion. This will be reflected in the case studies presented below, which show that the analyses have higher ozone values than the free model run at the location of the intrusion, whereas the PV patterns are unchanged. Within the framework of assimilation in a CTM model, the ozone distribution in the stratosphere and the troposphere is modified by the MLS ozone analyses, whereas dynamical information shown here by the 2 PVU iso-line is not.

\section{Meteorological situation and ozone fields analysis}

\subsection{Filamentary processes}

In this section we focus on 2 STE case studies of atmospheric features called streamers. Streamers which can be identified as filamentary structures of stratospheric air in the UTLS, have been characterised by Appenzeller and Davies (1992), and Appenzeller et al. (1996) with the help of water vapour satellite measurements. These patterns of high PV values (but also of high ozone values and low specific humidity), can stretch southward in an irreversible way, with a length of $2000 \mathrm{~km}$ to $3000 \mathrm{~km}$ and a maximum width of $200 \mathrm{~km}$. These streamers are a manifestation of Rossby wave breaking at mid latitudes (Postel and Hitchman, 1999). Streamers are considered as irreversible isentropic events (see Sect. 3), and as a synoptic scale mass exchange mechanism between the stratosphere and the troposphere. Sprenger et al. (2007) and Wernli et al. (2007) showed a relationship between STE and PV streamers.

Two types of streamers are defined (Thorncroft et al., 1993): Type I has an anticyclonic curve (linked to an anticyclone at its western edge) and can often break into a train of eddies, i.e., a PV low height anomaly train (Browning, 1993). These eddies roll up the stratospheric air with 
a) Potential vorticity
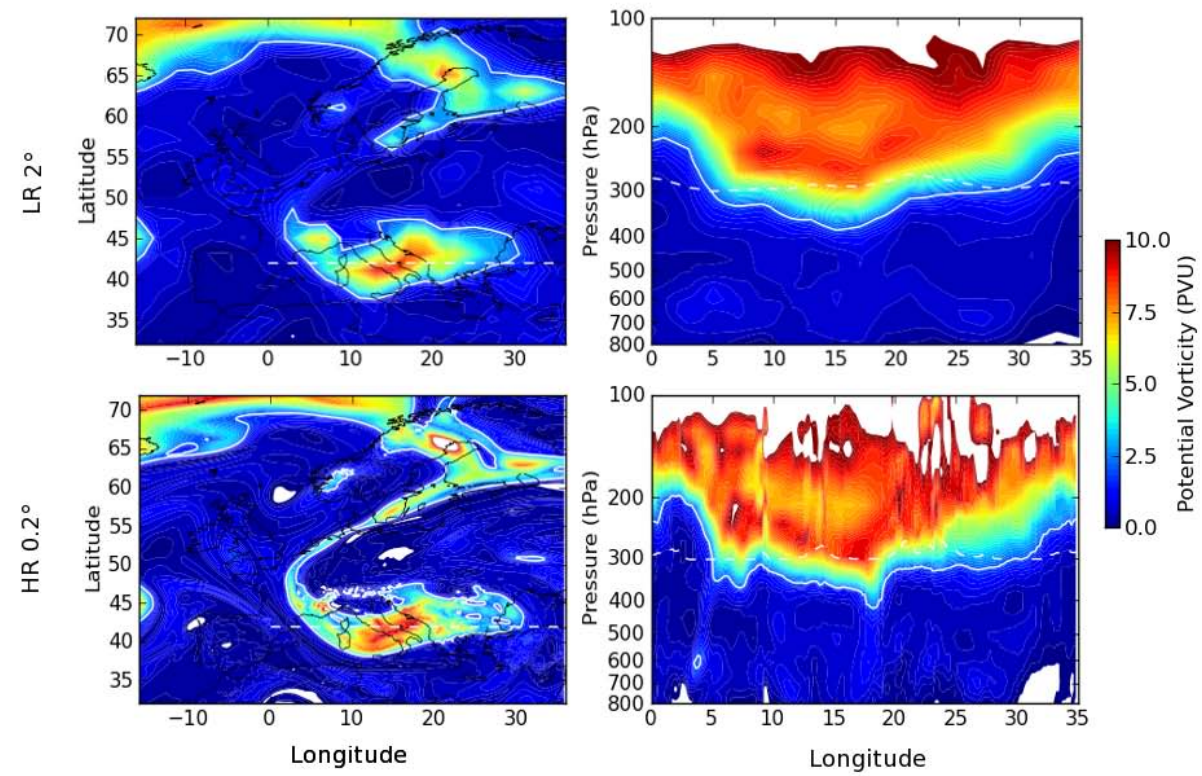

b) Horizontal wind

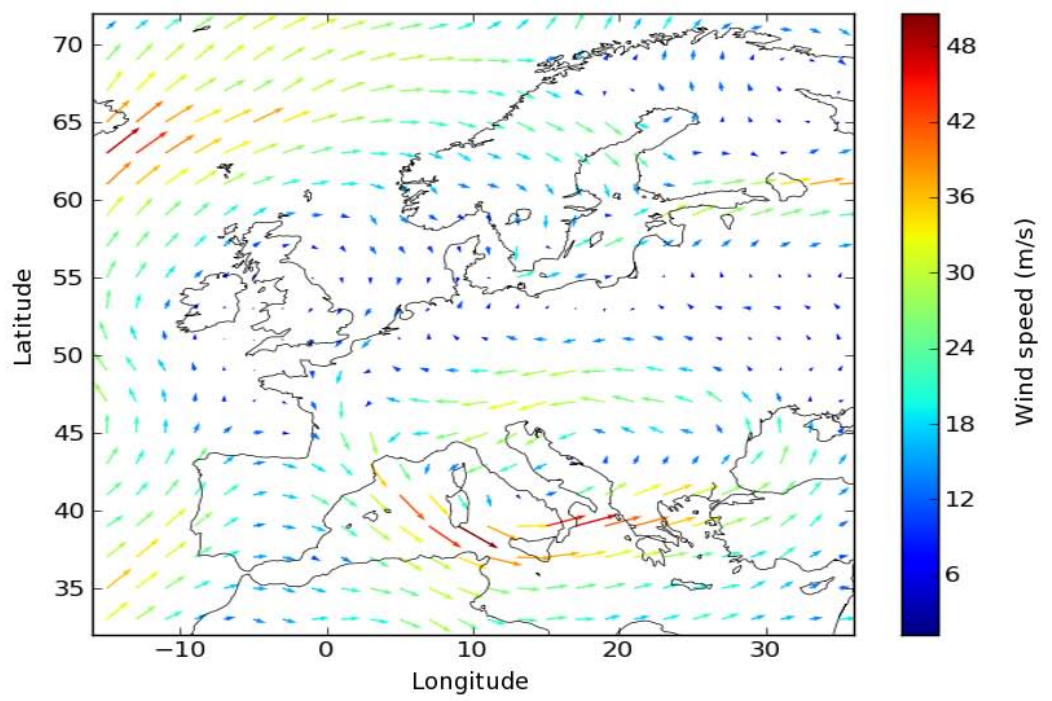

Fig. 3. Meteorological situation on 23 June 2009, 12:00 UT from ARPEGE analysis. (a) Potential vorticity fields, in potential vorticity units $\left(1 \mathrm{PVU}=1 \times 10^{6} \mathrm{~K} \mathrm{~kg}^{-1} \mathrm{~m}^{2} \mathrm{~s}^{-1}\right)$ from low $\left(2^{\circ}\right)$ horizontal resolution simulation (top) and high horizontal resolution $\left(0.2^{\circ}\right)$ simulation (bottom). Left hand side panels show longitude-latitude fields for a given model level; right hand side panels show longitude-pressure crosssections. The white dashed line associates the vertical and the horizontal distribution by showing the same location between left hand side and right hand side panels. The white solid lines identify the 2 PVU contour. (b) Horizontal wind fields at LR near $300 \mathrm{hPa}$.

the tropospheric air, which allows conditions for favourable mixing by increasing the surface area between the two air masses. Type II has a North-South orientation with a vortex at the southern tip (Appenzeller et al., 1996). Note that, not all STE is a result of irreversible isentropic events (Stohl et al., 2003).

\subsection{Case 1: stratospheric intrusion on 23 June 2009}

\subsubsection{Meteorological situation}

In this section, we describe a stratospheric intrusion which took place on 23 June 2009 over Europe and lasted 4.5 days (from 20 June, 06:00 UT, to 24 June, 18:00 UT). Figure 3a shows the horizontal distribution of PV for a model level in the UTLS (left hand side panels) and vertical cross-sections of the model (right hand side panels) during the main phase 
of the intrusion (23 June 2009, 12:00 UT) at two model resolutions (LR: $2^{\circ}, \mathrm{HR}: 0.2^{\circ}$ ). White solid lines identify the $2 \mathrm{PVU}$ iso-line. Characteristic signatures of the intruded air are high PV values. This pattern can be associated with the type I streamer described above (see Sect. 4.1). It has an anticyclonic curve over the northern part of the domain (Fig. 3b) and a NE-SW orientation from the North of the Baltic sea to the centre of France. A train of eddies is visible at the South tip of the streamer. Figure 3a shows a transitional period when both cyclonic and anticyclonic behaviour are evident (Thorncroft et al., 1993). On 23 June 2009 12:00 UT at a resolution of $0.2^{\circ}$ these eddies are not clearly visible. At HR and LR, this case study show high PV values intruding the troposphere. At upper tropospheric levels $(200 \mathrm{hPa}-300 \mathrm{hPa})$ $\mathrm{PV}$ values increase over the longitude range $5^{\circ} \mathrm{E}-25^{\circ} \mathrm{E}$ due to the strong (Fig. 3b) PV anomaly occurring above $200 \mathrm{hPa}$. The vertical distribution shows high stratospheric PV values ( $>2 \mathrm{PVU}$ ) below $300 \mathrm{hPa}$. At these pressure levels, rapid mixing by turbulence and convection may lead to irreversible STE events (Gouget et al., 2000).

\subsubsection{Comparison between the low resolution and the high resolution runs}

In this section we compare the PV fields from the LR runs and HR runs. On horizontal distributions, the HR allows an accurate representation of the streamers. Horizontal gradients are increased with the HR whereas the LR gives a very smooth representation of these streamers. The LR horizontal PV field shows high values (a PV anomaly) over Italy and South-East of France which do not seem to be linked by a streamer to the polar stratospheric air mass. The HR horizontal distributions of PV allow the representation in the UTLS of the filamentary structures that characterise the streamers. Fine vertical structures in the streamers are also captured in the HR run. We notice a vertical PV filamentary structure occurring at HR to the west of the PV height anomaly described in Sect. 4.2.1 ( $\left.5^{\circ} \mathrm{E}\right)$. At LR, these vertical structures are not captured. The increase in the horizontal resolution provides a more detailed streamer structure in the horizontal and in the vertical.

\subsubsection{Ozone analysis fields}

Figure 4 shows horizontal distributions for a model level in the UTLS (left hand side panels) and vertical cross-sections (right hand side panels) of ozone during the main phase of the intrusion (23 June 2009, 12:00 UT). Figure 4 compares the free model experiment and the analyses from the assimilation experiment, at the two model resolutions described in this paper (see Sect. 2.1). White solid lines identify the 2 PVU iso-line. Ozone fields and PV fields show similar patterns. These patterns are seen in the free run experiments but ozone values are increased in the MLS assimilation runs. The horizontal distributions of the MLS ozone analyses show higher ozone values than the free runs. Generally, the vertical cross sections from MLS ozone analyses show the vertical ozone gradient displaced downward in altitude where the STE takes place. The shape of the vertical ozone gradient in MLS ozone analyses follows more closely the $2 \mathrm{PVU}$ isoline. Qualitatively, MLS ozone analyses bring to the model an added value to the ozone distribution at the UTLS layers. MLS analyses also increase the ozone values below the $2 \mathrm{PVU}$ iso-line in the troposphere.

Regarding the improvement shown by the HR fields, we can conclude as for Sect. 4.2.2. Filamentary structures which cannot be seen or are smoothed in the LR runs are represented accurately in the HR runs. In this case, the NE-SW ozone filament over northern Europe is more clearly identified with sharper gradients and is identified by the $2 \mathrm{PVU}$ contour in the HR horizontal distribution. HR ozone vertical cross sections show a more detailed vertical ozone structure than LR ozone vertical cross sections. For example, the vertical ozone tropospheric patterns at $5^{\circ} \mathrm{E}$ between 300 and $500 \mathrm{hPa}$ for the HR MLS ozone analyses can be associated with the streamer structure.

To summarise, these filamentary structures of ozone visible at the HR runs are smoothed or not well represented in the LR runs. MLS analyses increase the ozone values by about 100 ppbv (parts per billion by volume) in the streamer structure in LR and HR.

\subsubsection{Comparison with independent datasets}

In this section a validation of MLS ozone analyses of this case study is performed using the WOUDC (World Ozone and Ultraviolet Radiation Data Centre) ozone sondes and the MOZAIC (Measurements of OZone, water vapour, carbon monoxide and nitrogen oxides by in-service AIrbus airCraft) aircraft flights. The MOZAIC program measures ozone and other species from commercial aircraft (Marenco et al., 1998). Comparison of the first two years of MOZAIC ozone data with ozone sonde network data showed good agreement (Thouret et al., 1998). The WOUDC is one of the five World Data Centres which are part of the Global Atmosphere Watch (GAW) program of the World Meteorological Organization (WMO).

In this case study two MOZAIC flights have been used: a flight on 23 June 2009 from Frankfurt $\left(50^{\circ} \mathrm{N}, 8^{\circ} \mathrm{E}\right.$, Germany) at $08: 13 \mathrm{UT}$ to Calgary $\left(51^{\circ} \mathrm{N}, 114^{\circ} \mathrm{W}\right.$, Canada) and a flight on 23 June 2009 from Frankfurt $\left(50^{\circ} \mathrm{N}, 8^{\circ} \mathrm{E}\right.$, Germany) at 13:00 UT to Philadelphia ( $39^{\circ} \mathrm{N}, 75^{\circ} \mathrm{W}$, US). In Fig. 5a, the runs at HR (solid lines) agree better with MOZAIC data (green line) than the LR runs (dashed lines). The two MOZAIC flight tracks cross the filament near $5^{\circ} \mathrm{E}$ and $52^{\circ} \mathrm{N}$ and identify a peak of ozone at this location. The use of HR improves considerably the ozone distribution. Peaks detected by the MOZAIC flights are well represented by the HR runs. Where the analyses and free model run fields at HR show the signature of the filament, the analyses are 

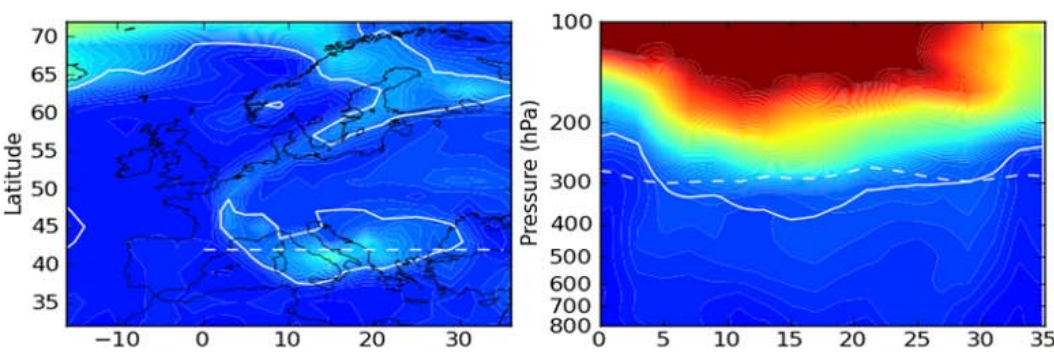

$\operatorname{LR}_{f} 2^{\circ}$
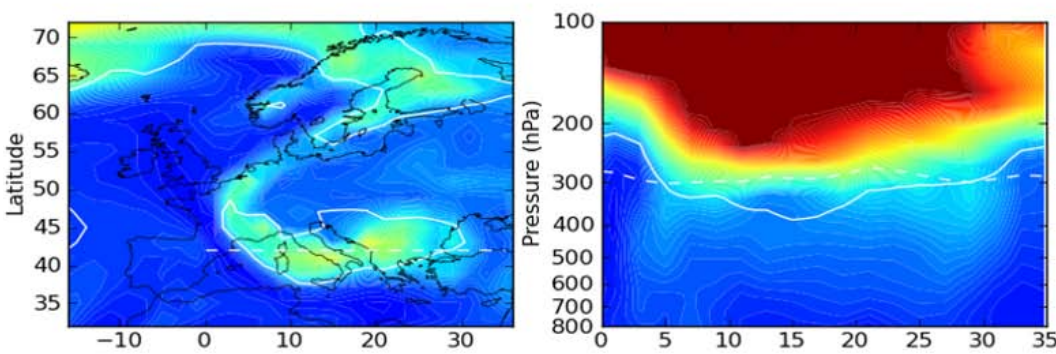

$\operatorname{LR}_{\mathrm{a}} 2^{\circ}$
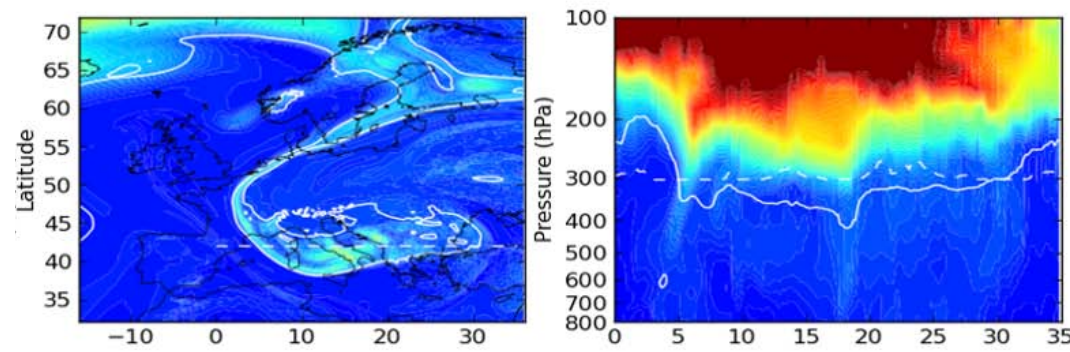

$\mathrm{HR}_{f} 0.2^{\circ}$
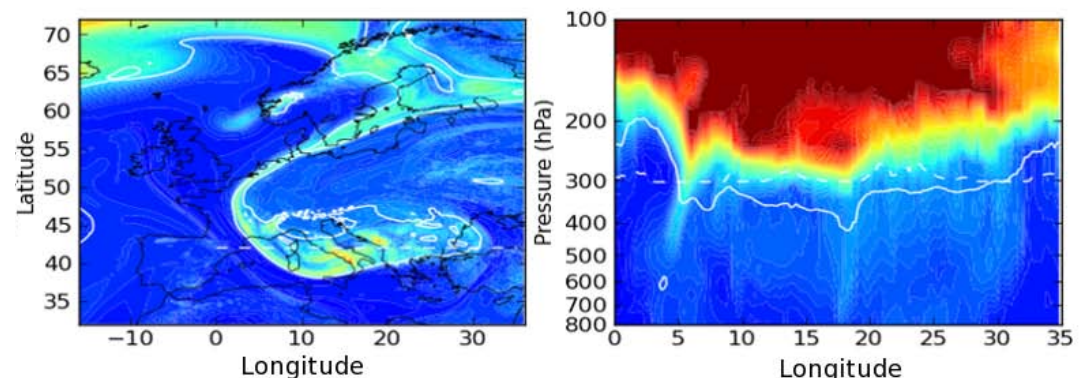

$\mathrm{HR}_{\mathrm{a}} 0.2^{\circ}$

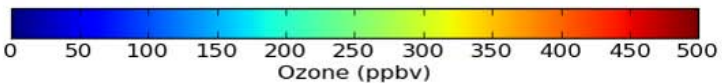

Fig. 4. Ozone fields for 23 June 2009, 12:00 UT, in ppbv (parts per billion by volume) for various experiments: $\mathrm{LR}_{\mathrm{f}}$ : Low Resolution $\left(2^{\circ}\right)$ free run; $\mathrm{LR}_{\mathrm{a}}$ : Low Resolution $\left(2^{\circ}\right)$ analyses; $\mathrm{HR}_{\mathrm{f}}$ : High Resolution $\left(0.2^{\circ}\right)$ free run and $\mathrm{HR}_{\mathrm{a}}$ : High Resolution $\left(0.2^{\circ}\right)$ analyses. Left hand side panels show longitude-latitude fields for a given model level; right hand side panels show longitude-pressure cross-sections. White dashed line associate vertical and horizontal distribution by showing the same location between left hand side and right hand side panels. The white solid lines identify the 2 PVU contour.

significantly closer to the MOZAIC data. The measured peak maximum by MOZAIC flights is between $7 \mathrm{mPa}$ and $8 \mathrm{mPa}$, whereas LR free run, LR MLS analyses, HR free run and HR MLS analyses provides ozone maxima of $3 \mathrm{mPa}, 6 \mathrm{mPa}$, $5 \mathrm{mPa}$ and $7.5 \mathrm{mPa}$, respectively. This comparison shows that the MLS ozone analysed fields at HR can improve the representation of UTLS ozone during a stratospheric intrusion event.
Unfortunately there are no WOUDC vertical records well co-located in space and time with the stratospheric intrusion event. We thus compare our results with a sonde launched at Legionowo (Poland: $52.4^{\circ} \mathrm{N}, 21^{\circ} \mathrm{E}$ ) at $11: 17 \mathrm{UT}$ on 24 June 2009. In Fig. 6, the ozone sonde measurements (green line) are compared with the LR free run (blue dashed line), the LR MLS analyses (red dashed line), the HR free run (solid blue line) and the HR MLS analyses (solid red line). These profiles show that between $100 \mathrm{hPa}$ and $300 \mathrm{hPa}$ MLS ozone 
a)

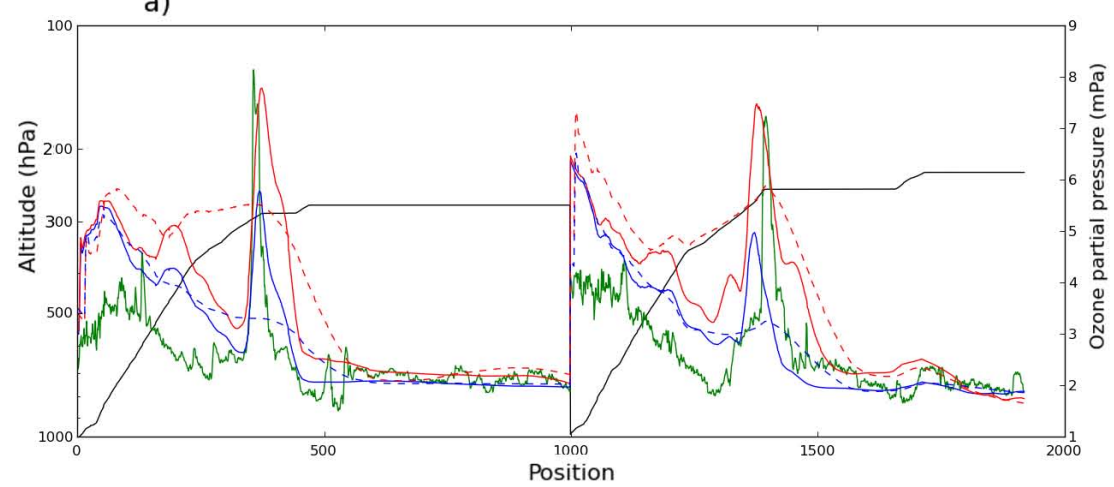

b)

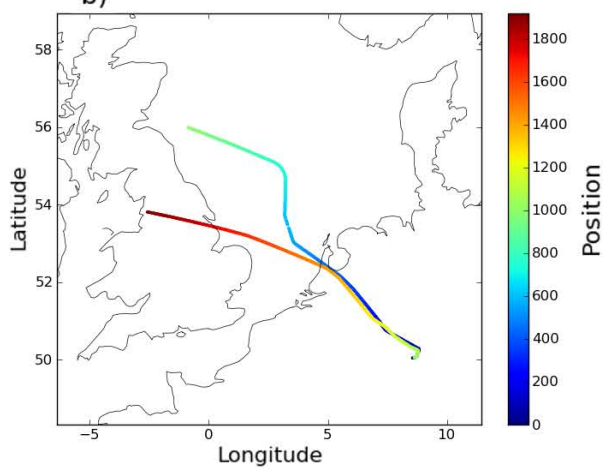

Fig. 5. Left hand side panel: ozone data from MOZAIC (green line), free MOCAGE run (blue lines) and analyses fields (red lines), in $\mathrm{mPa}\left(10^{-3}\right.$ Pascals, right hand side y-axis); flight level (black line), in hPa $\left(10^{2}\right.$ Pascals, left hand side y-axis). Low resolution $\left(2^{\circ}\right)$ and high resolution $\left(0.2^{\circ}\right)$ results are marked as dashed lines and solid lines, respectively. Right hand side panel: flight tracks on 23 June 2009 . Position 0 to 1000: starting at Frankfurt $\left(50^{\circ} \mathrm{N}, 8^{\circ} \mathrm{E}\right.$, Germany, 08:13 UT) to Calgary ( $51^{\circ} \mathrm{N}, 114^{\circ} \mathrm{W}$, Canada). Position 1000 to 1900 : starting at Frankfurt $\left(50^{\circ} \mathrm{N}, 8^{\circ} \mathrm{E}\right.$, Germany, 13:00 UT) to Philadelphia $\left(39^{\circ} \mathrm{N}, 75^{\circ} \mathrm{W}, \mathrm{US}\right)$.

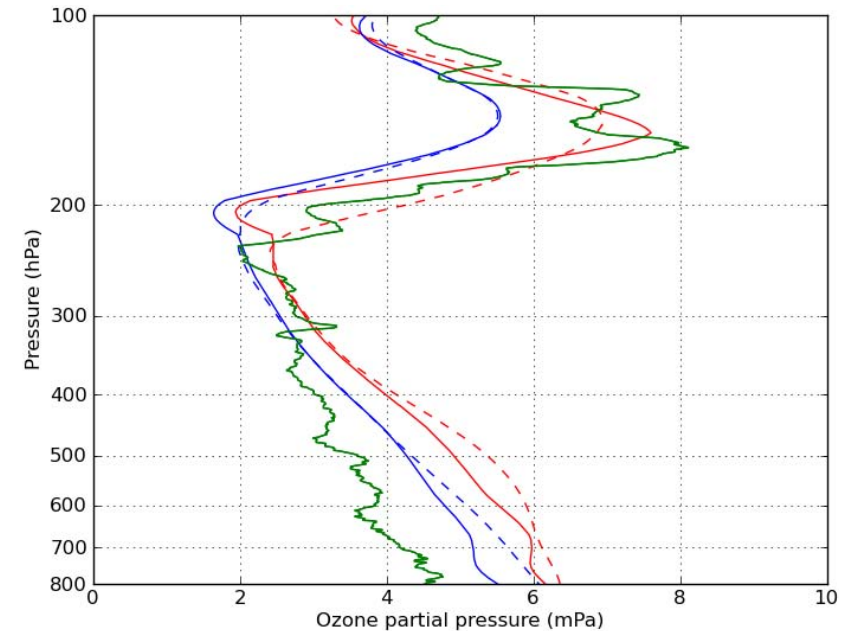

Fig. 6. Ozone profiles in $\mathrm{mPa}$ from a sonde over Legionowo $\left(52.4^{\circ} \mathrm{N}, 21.97^{\circ} \mathrm{E}\right.$, Poland; green line, launched at 11:17 UT on 24 June 2009), from the free MOCAGE run (blue lines) and from analyses (red lines). Low resolution $\left(2^{\circ}\right)$ and high resolution $\left(0.2^{\circ}\right)$ results are represented by dashed and solid lines, respectively.

analyses are in better agreement with observations than the free run. In this height range, the improvement of the HR MLS ozone analyses is characterised by a maximum closer to the observations than for the LR MLS ozone analyses. Compared to the tropospheric ozone sonde values, MLS ozone analyses show no improvement but increase the positive bias already seen in the free model runs. Between $400 \mathrm{hPa}$ and $800 \mathrm{hPa}$ free model runs show a bias of around $1 \mathrm{mPa}$ and MLS analyses show a bias of around $2 \mathrm{mPa}$.

\subsection{Case 2: stratospheric intrusion on 17 July 2009}

\subsubsection{Meteorological situation}

This case describes a stratospheric intrusion which took place on 17 July 2009 over Europe and lasted 3.5 days (from 16 July, 06:00 UT, to 19 July, 18:00 UT). Figure $7 \mathrm{~b}$ shows the horizontal distribution for a model level in the UTLS (left hand side panels) and the longitude-pressure cross-sections (right hand side panels) of PV during the main phase of the intrusion (17 July 2009, 15:00 UT) at the two model horizontal resolutions. White solid lines identify the $2 \mathrm{PVU}$ isoline. This pattern can be associated with a type II streamer described above (see Sect. 4.1). The streamer has a more North-South orientation than the previous case study (see Sect. 4.2.1), from the North of Ireland to the South of France. At the South tip of the streamer, a vortex over France is visible at HR. The vertical cross sections of PV fields (HR and LR), show a V-shaped deep intrusion. At upper tropospheric levels (200 hPa-300 hPa) PV values increase between the longitude range $15^{\circ} \mathrm{W}-8^{\circ} \mathrm{E}$ due to the strong cyclonic (Fig. 7a) PV anomaly occurring above $200 \mathrm{hPa}$. The vertical distribution shows high stratospheric PV values (>2 PVU) below $300 \mathrm{hPa}$.

\subsubsection{Comparison between the low resolution and the high resolution runs}

In this section we compare the PV fields from the LR runs and HR runs. Horizontal gradients are increased with the HR whereas the LR gives a very smooth representation of these streamers. The HR horizontal distributions of PV allow the representation in the UTLS of the filamentary structures that characterise the streamers. Fine vertical structures in the streamers are also captured in the HR runs. We notice a vertical PV filamentary structure occurring at HR to the west of 
a) Potential vorticity
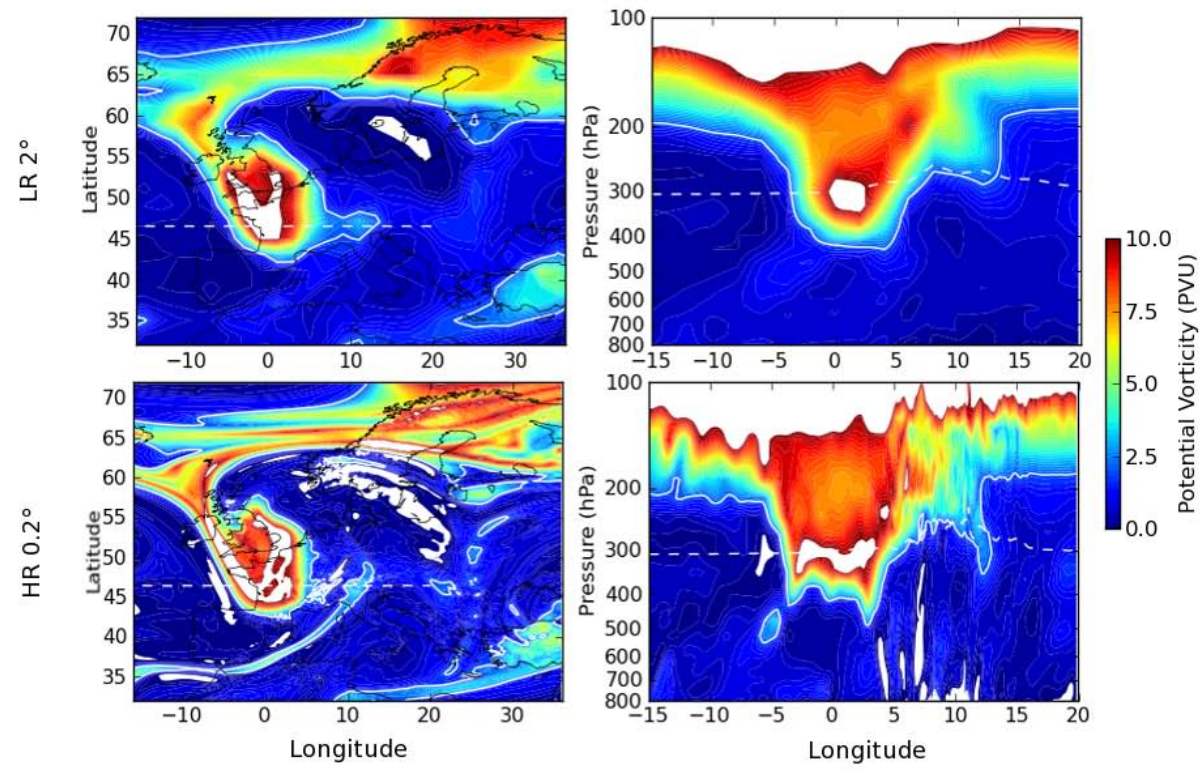

b) Horizontal wind

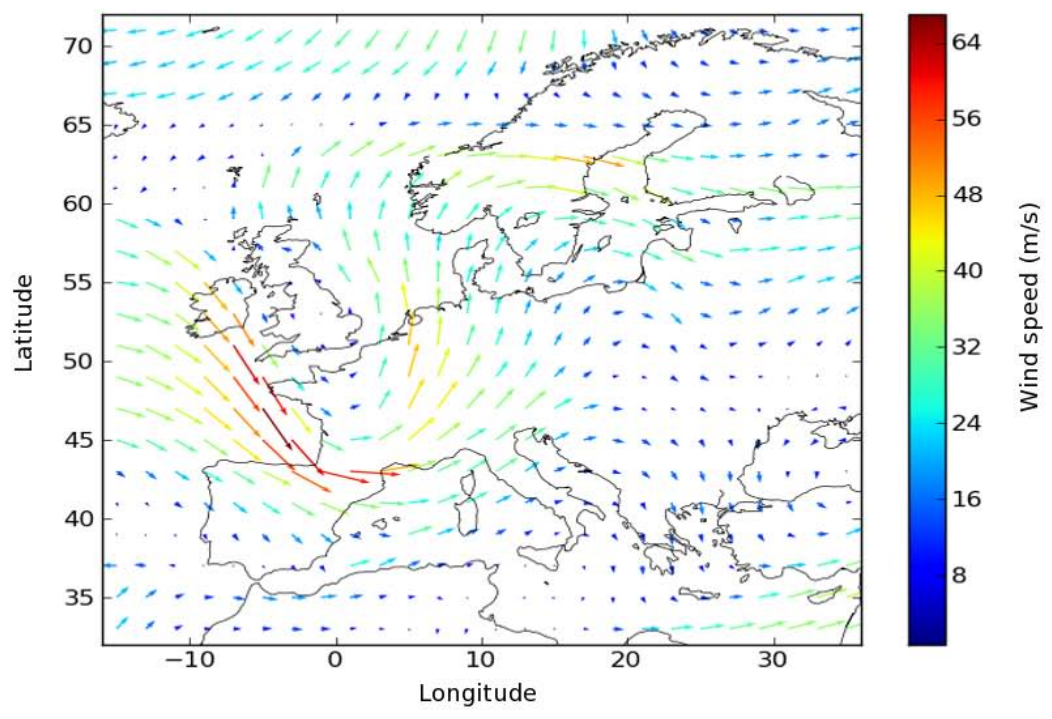

Fig. 7. Meteorological situation on 17 July 2009, 15:00 UT from ARPEGE analysis. (a) Potential vorticity fields, in potential vorticity unit $\left(1 \mathrm{PVU}=1 \times 10^{6} \mathrm{~K} \mathrm{~kg}^{-1} \mathrm{~m}^{2} \mathrm{~s}^{-1}\right)$ from low horizontal resolution $\left(2^{\circ}\right)$ simulation (top) and high horizontal resolution $\left(0.2^{\circ}\right)$ simulation (bottom). Left hand side panels show longitude-latitude fields for a given model level; right hand side panels show longitude-pressure crosssections. The white dashed line associates the vertical and the horizontal distribution by showing the same location between left hand side and right hand side panels. The white solid lines identify the 2 PVU contour. (b) Horizontal wind fields at LR near $300 \mathrm{hPa}$.

the PV height anomaly described in Sect. 4.2.2 $\left(5^{\circ} \mathrm{W}\right)$. At LR, these vertical structures are also seen in this case study but are less detailed. As described in Sect. 4.2.2 the increase of the horizontal resolution provides a more detailed streamer structure in the horizontal but also in the vertical.

\subsubsection{Ozone analysis fields}

Figure 8 shows horizontal distributions for a model level in the UTLS (left hand side panels) and vertical cross-sections (right hand side panels) of ozone during the main phase of the intrusion (17 July 2009, 15:00 UT). Figure 8 compares the free model experiment and the analyses from the assimilation experiment, at two model resolutions (see Sect. 2.1). White solid lines identify the 2 PVU iso-line. Ozone fields and PV fields show similar patterns. These ozone patterns are seen in the free run experiments but ozone values are increased in the MLS assimilation runs. Generally, the ozone vertical cross sections from MLS analyses show a vertical ozone gradient displaced downward in altitude, where the 

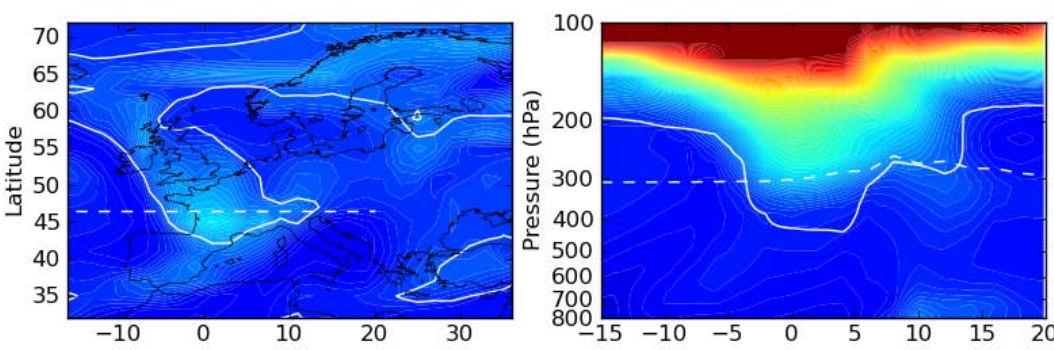

$\mathrm{LR}_{\mathrm{f}} 2^{\circ}$
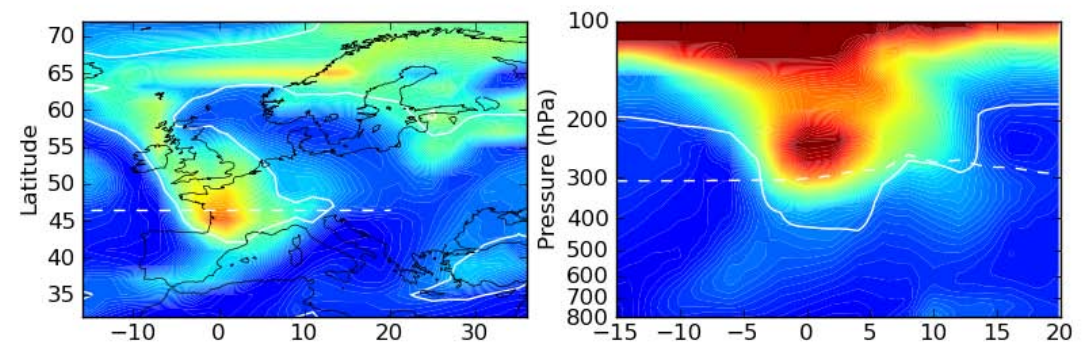

$\mathrm{LR}_{\mathrm{a}} 2^{\circ}$
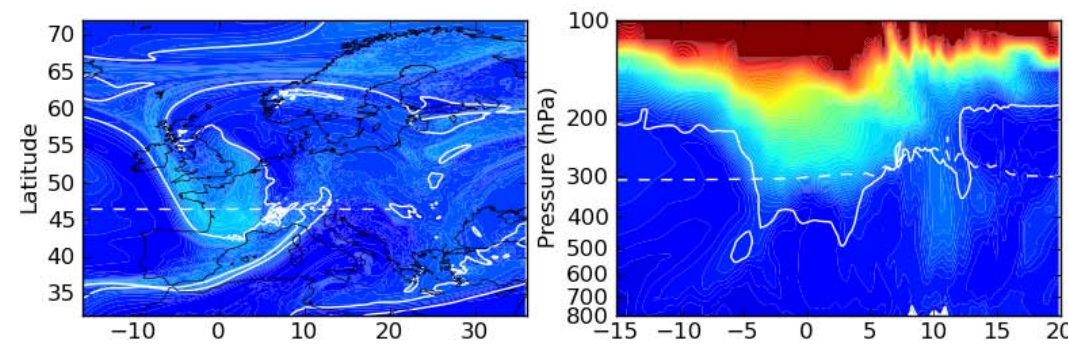

$\mathrm{HR}_{\mathrm{f}} 0.2^{\circ}$
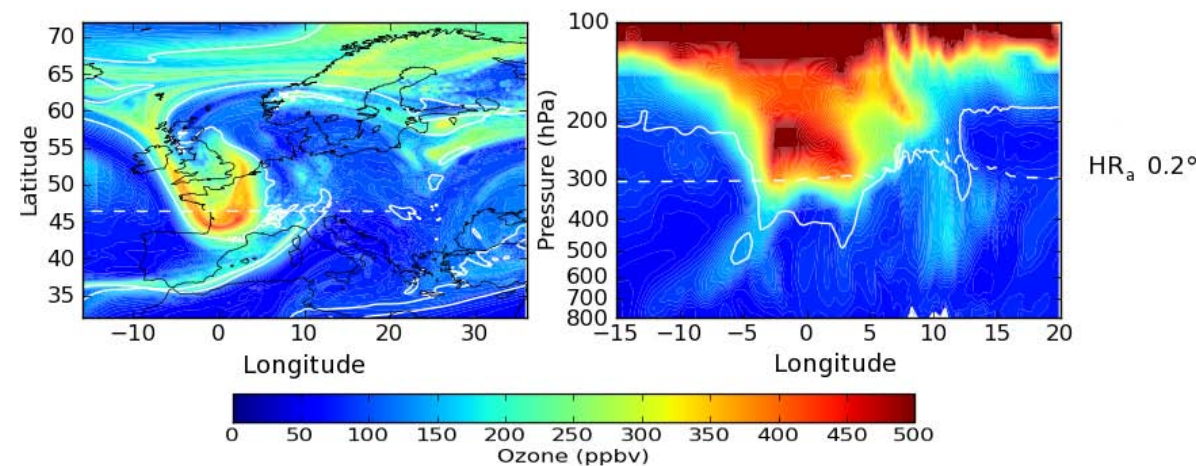

Fig. 8. Ozone fields for 17 July 2009, 15:00 UT, in ppbv (parts per billion by volume) for various experiments: $\mathrm{LR}_{\mathrm{f}}$ : Low Resolution $\left(2^{\circ}\right)$ free run; $\mathrm{LR}_{\mathrm{a}}$ : Low Resolution $\left(2^{\circ}\right)$ analyses; $\mathrm{HR}_{\mathrm{f}}$ : High Resolution $\left(0.2^{\circ}\right)$ free run and $\mathrm{HR}_{\mathrm{a}}$ : High Resolution $\left(0.2^{\circ}\right)$ analyses. Left hand side panels show longitude-latitude fields for a given model level; right hand side panels show longitude-pressure cross-sections. White dashed line associate vertical and horizontal distribution by showing the same location between left hand side and right hand side panels. The white solid lines identify the 2 PVU contour.

STE takes place. The shape of the vertical ozone gradient in MLS ozone analyses follows more closely the 2 PVU isoline.

Regarding the improvement shown by the HR fields, we can conclude as for Sect. 4.2.3 Filamentary structures not seen or smoothed in the LR runs are represented accurately in the HR runs. The NE-SW ozone filament over the Mediterranean sea is only seen on the HR horizontal distribution. This filament corresponds in the longitude-pressure cross sections to the high volume mixing ratio (VMR) of ozone tropospheric patterns visible at $13^{\circ} \mathrm{E}$ and between 300 and $500 \mathrm{hPa}$ for the HR MLS ozone analysis.

To summarise, these filamentary structures of ozone visible at the HR runs are smoothed or not well represented in the LR runs. At HR, ozone filamentary patterns are more marked in the MLS ozone analyses. 

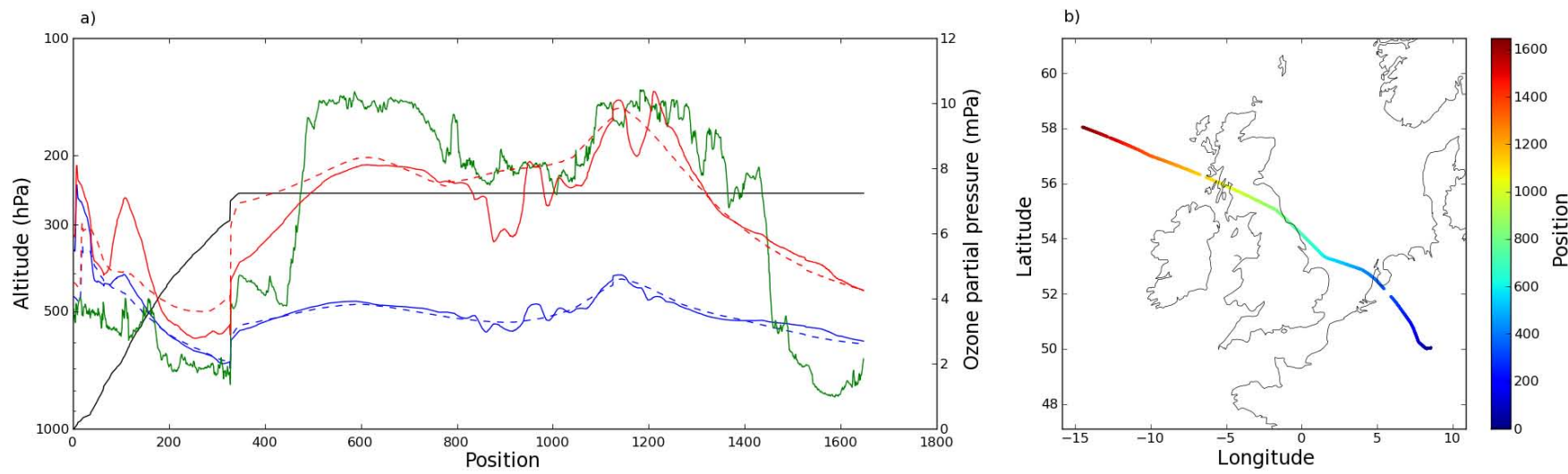

Fig. 9. Left hand side panel: ozone data from MOZAIC (green line), free MOCAGE run (blue lines) and analyses fields (red lines), units of $\mathrm{mPa}$ (right hand side y-axis); flight level (black line), units of $\mathrm{hPa}$ (left hand side y-axis). Low resolution $\left(2^{\circ}\right)$ and righ resolution $\left(0.2^{\circ}\right)$ results are marked as dashed lines and solid lines, respectively. Right hand side panel: flight track on 17 july 2009. Position 0 to 1700 : starting at Frankfurt $\left(50^{\circ} \mathrm{N}, 8^{\circ} \mathrm{E}\right.$, Germany, $\left.11: 57 \mathrm{UT}\right)$ to Atlanta $\left(33^{\circ} \mathrm{N}, 84^{\circ}\right.$, US).

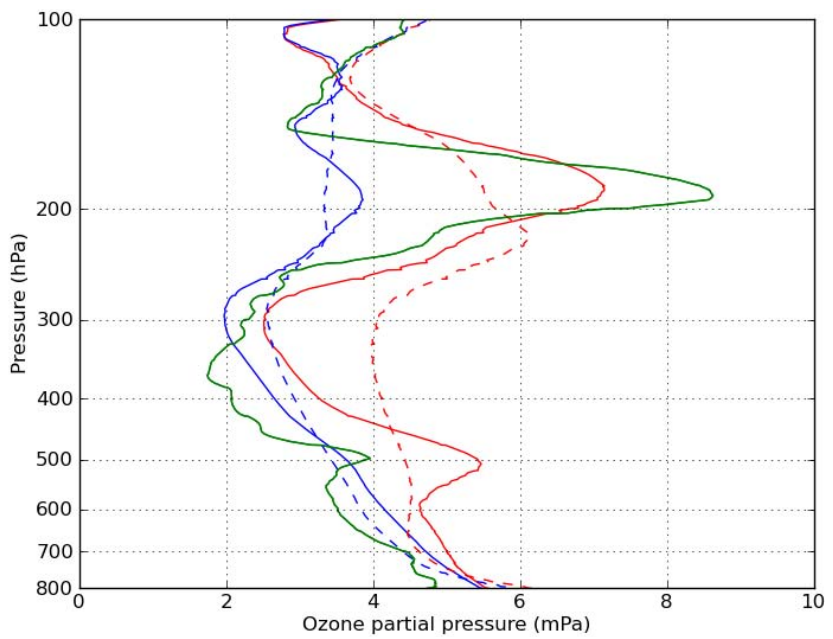

Fig. 10. Ozone profiles, $\mathrm{mPa}$, from a sonde over Payerne $\left(46.5^{\circ} \mathrm{N}\right.$, $6.6^{\circ} \mathrm{E}$; green line, launched at 11:00 UT on 17 July 2009), from the free MOCAGE run (blue lines) and from analyses (red lines). Low resolution $\left(2^{\circ}\right)$ and high resolution $\left(0.2^{\circ}\right)$ results are represented by dashed and solid lines, respectively.

\subsubsection{Comparison with independent datasets}

In this section a validation of MLS ozone analyses during the two case studies is performed using the WOUDC ozone sondes and the MOZAIC aircraft flights.

The MOZAIC ozone data used in this study comes from a flight on 17 July 2009 from Frankfurt $\left(50^{\circ} \mathrm{N}, 8^{\circ} \mathrm{E}\right.$, Germany) at 11:57 UT to Atlanta $\left(33^{\circ} \mathrm{N}, 84^{\circ} \mathrm{W}\right.$, US) and left the regional domain at 14:16 UT. In Fig. 9a, the ozone analyses (red lines) agree better with MOZAIC data (green line) than the free model (blue lines). The MOZAIC flight track crosses the intrusion between $3.5^{\circ} \mathrm{E}$ and $1.5^{\circ} \mathrm{W}$. MLS analysed fields show a better agreement with MOZAIC data than the free model run fields. At the location of the intrusion the MLS analyses are significantly closer to the MOZAIC data.

At 11:00 UT on 17 July 2009, a MeteoSwiss ozone sonde was launched from Payerne (Switzerland; $46.5^{\circ} \mathrm{N}, 6.6^{\circ} \mathrm{E}$ ). In Fig. 10, the ozone sonde measurements (green line) are compared with the four different experiments in this study. Figure 10 shows a maximum located at $190 \mathrm{hPa}$ in the UTLS. The analyses at high resolution are closer to the ozone sonde data in terms of magnitude and variability with height providing the best match with the ozone profile changes on the vertical. This maximum represents the east side of the Vshaped intrusion identified on the left hand side panel of Fig. 8. HR analyses improve the representation of this maximum. It has been shown that stratospheric intrusions typically form filamentary structures (Holton et al., 1995) in the free troposphere, which appear as laminae (Stohl et al., 2003) in the ozone profile. A second maximum located at $500 \mathrm{hPa}$ is only represented by the MLS ozone analyses at HR and also detected by the ozone sonde. This tropospheric ozone maximum shows the benefits of HR MLS ozone analyses in the troposphere. Vertical structure is improved in the UTLS and in the free troposphere appearing as laminae or as ozone maxima in the ozone profile (Figs. 6 and 10). Results indicate that the improvement in the representation of the UTLS and free troposphere structures is owing to the use of assimilation and HR. A discussion of the origin of the maximum of ozone in troposphere is detailed in Sect. 5.1.

\subsection{Impact in the troposphere}

To describe in a complete way the phenomena taking place during the case studies we need to refer to both the UTLS and the troposphere. Although there are no increments below $250 \mathrm{hPa}$, the information from the increments above $250 \mathrm{hPa}$ will be propagated to the troposphere by the model. Therefore the increments can impact the ozone field below 


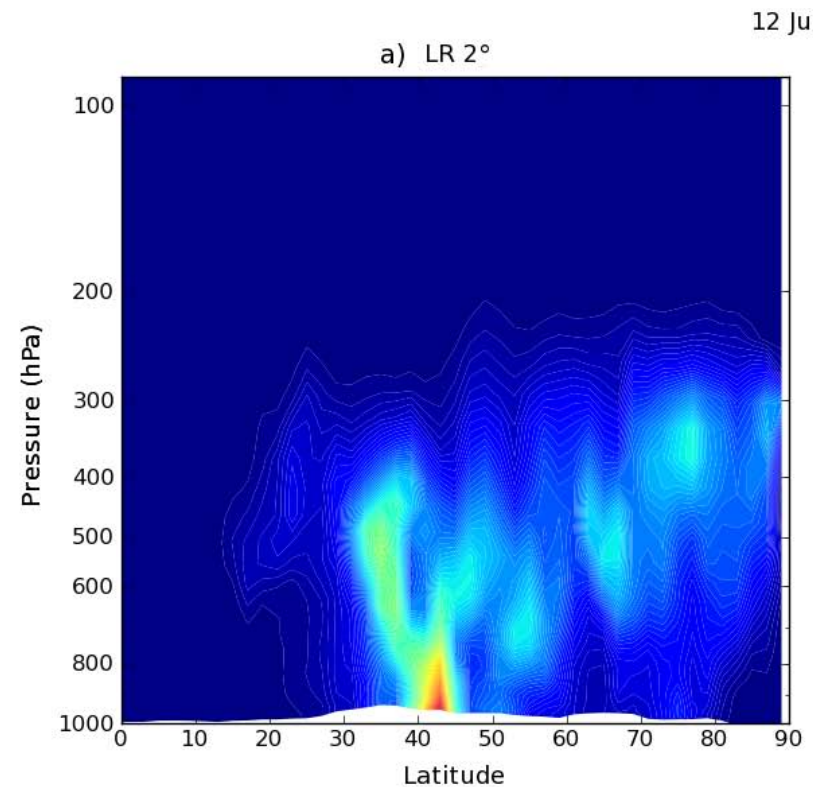

Fig. 11. Zonal means of a tracer initialised backward trajectories. concentration values are arbitrary: from 0 to a (the maximum value).

$250 \mathrm{hPa}$. Between about $300 \mathrm{hPa}$ and $800 \mathrm{hPa}$, in the free troposphere, the free model run at HR is closer than HR MLS ozone analyses to the ozone sonde data in terms of magnitude. In other words the MLS ozone analyses increase the positive bias in the troposphere which already exists in the free runs. This suggest that too much stratospheric ozone is advected through the tropopause. The high horizontal resolution and vertical resolution used in this study are still too coarse to represent faithfully the filamentary structures of ozone in the UTLS measured by MOZAIC aircraft and ozone sondes. For example in case study 2 (Fig. 7), the observed filament is very thin and horizontal ozone gradients in the neighbourhood are very strong. MLS ozone analyses with $0.2^{\circ}(\sim 20 \mathrm{~km})$ horizontal resolution and $800 \mathrm{~m}$ vertical resolution have hourly temporal resolution while the MOZAIC data has a sampling frequency of $4 \mathrm{~s}$ corresponding to a distance of $1 \mathrm{~km}$ between each measurements. The MLS ozone analyses have a good estimation of the maximum values, but spatial gradients are smoothed due to the coarse model resolution. Then MLS ozone analyses have a positive bias between 3 and $5 \mathrm{hPa}$ (see Fig. 5) in the neighbourhood of the filaments. This means fine structures in the ozone analyses contain too much ozone in the UTLS layers. In other words mixing ratios at the dynamical tropopause (2 PVU for example) will be overestimated. This suggests that MLS ozone analyses bring more ozone from stratosphere to troposphere than the free run. This overestimation of ozone values is stronger at LR than at HR, due to the lower resolution at LR. This also suggest that LR brings more ozone from the stratosphere to the troposphere than HR.

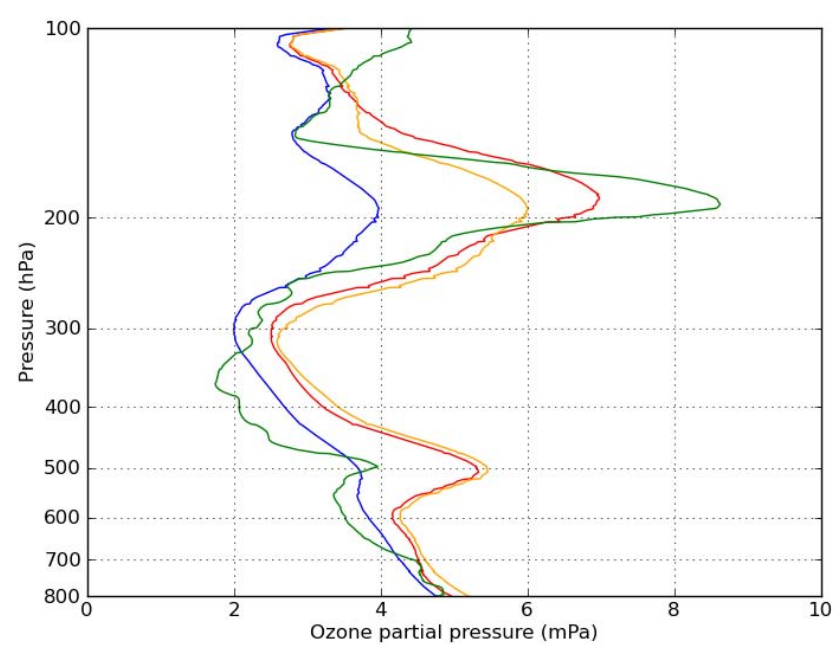

Fig. 12. Ozone profiles, $\mathrm{mPa}$, from a sonde over Payerne $\left(46.5^{\circ} \mathrm{N}\right.$, $6.6^{\circ} \mathrm{E}$; green line, launched at 11:00 UT on 17 July 2009), from the free MOCAGE run (blue line), from analyses (red line) and forecasted run initialised with MLS anlyses at 00:00 UT on 15 July 2009 (orange line). All experiments are from High Resolution $\left(0.2^{\circ}\right)$ runs.

\section{Discussion}

\subsection{Backward trajectories: impact of high resolution}

A good example of tropospheric impact is shown on figure 10 (see Sect. 4.3.4) where a tropospheric ozone maximum structure was observed by the WOUDC profile and was reasonably well represented by the HR MLS ozone analyses. To identify the origin of the air mass where the tropospheric 


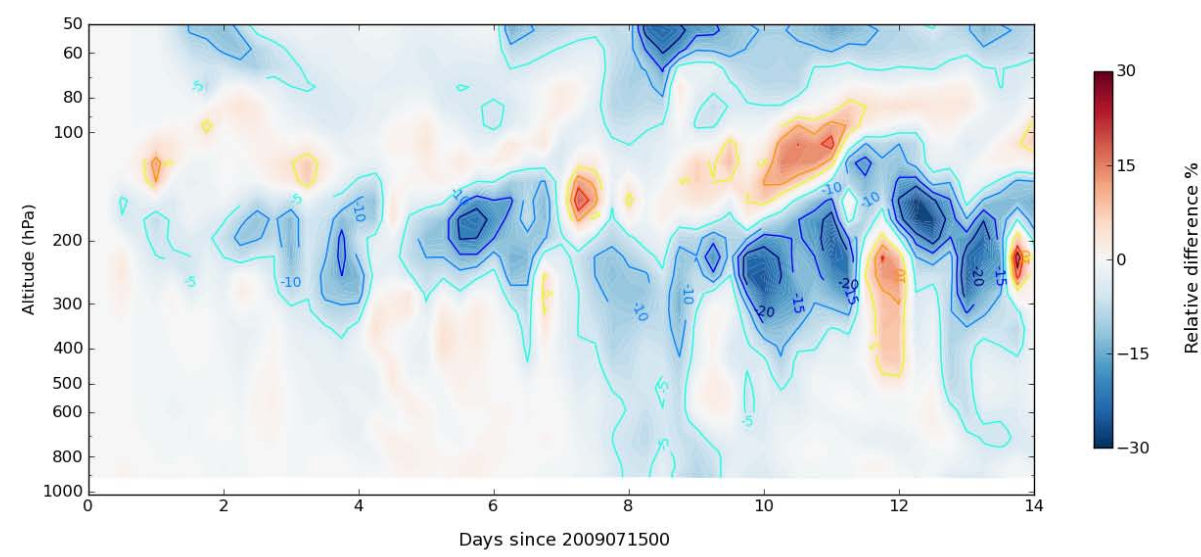

Fig. 13. Hovmuller diagram of the profile: (Forecast-MLS ozone analyses) in $\%$, averaged between $44^{\circ} \mathrm{N}-48^{\circ} \mathrm{N}$ and $5^{\circ} \mathrm{W}-9^{\circ} \mathrm{W}(\mathrm{Switzer}-$ land). Forecast is initialised from MLS ozone analyses on 15 July 2009 00:00 UT.

ozone maximum takes place, we use MOCAGE to calculate backward trajectories for case study 2 (17 July 2009). The tracer was initialised between $400 \mathrm{hPa}$ and $600 \mathrm{hPa}$ on 17 July 2009 at 11:00 UT. The model is initialised for the global domain (LR) and for the regional domain (HR). Note that the global domain is used to constrain the regional domain. Lateral boundary conditions for the regional domain come from the global domain. If tracers are advected out of the regional domain the tracer is then visible on the global domain. Figure 11 shows the zonal means of tracer concentration in the Northern Hemisphere five and a half days before (12 July 00:00 UT) the initialisation. Differences are significant in the backward trajectories for the two experiments. We observe a larger part of the tracers around the polar UTLS for the HR run whereas it is less evident for the LR run where the larger part of the tracers are located in the mid troposphere at middle latitudes. The LR run presents a part of the tracers close to the surface around $42^{\circ} \mathrm{N}$. Different to the LR run, the HR run clearly shows that the tropospheric maximum comes from a stratospheric intrusion that occurred few days before at Northern latitudes. It is shown that the HR run is able to represent tropospheric features coming from the lower stratosphere; this is not the case for LR runs.

\subsection{Ozone forecasts at high resolution: impact of MLS ozone analyses}

To quantify the tropospheric impact of the MLS assimilation on the stratosphere, a forecast of two weeks has been done. The initial state is the MLS ozone analyses on 15 July 2009 00:00 UT and the forecast ends 14 days later on 29 July 2009 00:00 UT. At first we compare the forecast to the WOUDC profile at Payerne on 17 July 2009 11:00 UT (Fig. 12). Two and a half days after the start of the forecast, the maximum of ozone in the UTLS decreases but the stratospheric and the free tropospheric profiles show no significant changes. As already shown in Fig. 1 the largest impact of MLS is located in the UTLS region. The transport of ozone from UTLS to the free troposphere takes a few days. The advantage of MLS ozone analyses (e.g. revealing ozone features in the free troposphere) can be used to forecast the free troposphere for about a week. Figure 13 shows the relative difference between forecasts and the MLS ozone analyses until the end of July. The largest difference is located at the UTLS layers and increases with time. In the first seven days of the forecast the difference in the free troposphere (below $300 \mathrm{hPa}$ ) is very small, under $5 \%$. By constraining ozone at the UTLS, tropospheric forecasts still contain after 7 days a strong contribution from the MLS observations. By using MLS ozone analyses at high resolution these tropospheric features (e.g. maxima of ozone in tropospheric profiles) can be forecast for a week. Even if MLS ozone analyses are biased in the free troposphere, this information on ozone features likely plays a non-negligible effect in the the tropospheric ozone budget, which will be investigated in further studies. Studying the tropospheric ozone budget is out of the scope of this paper.

\section{Conclusions}

In this paper we show the benefit of high horizontal resolution and MLS ozone assimilation on STE events. We use assimilation of MLS ozone profiles to constrain the MOCAGE CTM in the UTLS at middle and high latitudes. The study is conducted over Europe at low horizontal resolution $\left(2^{\circ}\right)$ and high horizontal resolution $\left(0.2^{\circ}\right)$. The assimilation of MLS ozone tends to increase the ozone concentration in UTLS levels in polar and middle latitudes and we show the impact of this increase on the free troposphere. It is shown that the assimilation increments, advected through the tropopause, also affect significantly the free troposphere. The added value of MLS ozone assimilation and its impact on the troposphere are illustrated using two case studies. 
These case studies (23 June 2009 and 17 July 2009) which both show a stratospheric intrusion, are detailed in the paper. The combination of high horizontal resolution and MLS ozone assimilation allows more realistic of UTLS ozone fields. High resolution runs are able to represent very thin filamentary structures of potential vorticity and ozone which characterise a STE. These structures of ozone are described more realistically in the MLS ozone analyses. The fidelity of the ozone analyses is assessed by comparison against independent measurements from MOZAIC aircraft and WOUDC ozone sondes. In both cases, comparison with MOZAIC flight data shows that the ozone analyses at the two resolutions provide a better description of the UTLS and the stratospheric intrusions, than the free model run. In particular, at high horizontal resolution the UTLS shows fine ozone structures. In addition, the comparison with ozone sonde measurements shows that the high horizontal resolution improves the representation of the UTLS. Despite a low aspect ratio (i.e. a low vertical resolution) in the UTLS at high horizontal resolution, MLS ozone analyses improve the vertical structures of the ozone fields (e.g. have stronger gradients). The transport at high resolution in the free troposphere reveals a realistic maximum of tropospheric ozone at $500 \mathrm{hPa}$ (17 July 2009 case) not seen in the low resolution case. However, we found a bias in the free troposphere between the ozone analysis and the in-situ data at the resolutions used. This is likely due to a too coarse model resolution in comparison to the MOZAIC data resolution. The model is unable to represent the strong gradients shown in MOZAIC data. This affects significantly the UTLS by increasing the concentration of ozone transported into the free troposphere, and could explain the bias.

It has been shown that vertical structures in tropospheric ozone profiles appearing as laminae in high horizontal resolution MLS ozone analyses come from the UTLS at high latitudes. By using backward trajectories, we show that these structures, which only appear at high resolution come from the UTLS region at high latitudes. In addition, we use MLS ozone analyses at high horizontal resolution to forecast the tropospheric ozone features. After 2.5 days the forecast vertical tropospheric profile is very close to the MLS ozone analysis which has a better representation of tropospheric ozone laminae structures than the free run. After 7 days the difference between forecast and MLS ozone analyses in the troposphere becomes significant (greater than $5 \%$ ). This confirms that improving the ozone in the UTLS region using MLS ozone data, improves the ozone distribution in the free troposphere revealing realistic ozone maxima in the ozone profile.

To improve the variability on tropospheric ozone and also to improve the absolute value of tropospheric ozone, we propose in a further study to extend the geometry of the observations assimilated by combining stratospheric limb observations with tropospheric column nadir observations.
Acknowledgements. We thank the reviewers for their constructive comments that helped to improve the article. This work was funded by the Centre National de Recherches Scientifiques (CNRS) and the Centre National de Recherches Météorologiques (CNRM) of Météo-France. VHP, JLA, LEA and WL are supported by the RTRA/STAE (POGEQA project). JLA thanks also the Région Midi Pyrénées (INFOAIR project). Thanks to the WOUDC to provide ozone sonde data sets. The authors acknowledge for the strong support of the European Commission, Airbus, and the Airlines (Lufthansa, Austrian, Air France) who carry free of charge the MOZAIC equipment and perform the maintenance since 1994. MOZAIC is presently funded by INSU-CNRS (France), Météo-France, and Forschungszentrum (FZJ, Julich, Germany). The MOZAIC data based is supported by ETHER (CNES and INSU-CNRS).

Edited by: P. Haynes

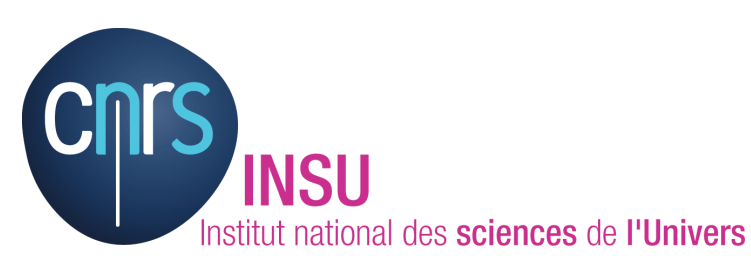

The publication of this article is financed by CNRS-INSU.

\section{References}

Appenzeller, C. and Davies, H. C.: Structure of stratospheric intrusion into the troposphere, Nature, 358, 570-572, 1992.

Appenzeller, C., Davies, H. C., and Norton, W. A.: Fragmentation of stratospheric intrusions, J. Geophys. Res., 101, 1435-1456, 1996.

Bechtold, P., Bazile, E., Guichard, F., Mascart, P., and Richard, E.: A mass-flux convection scheme for regional and global models, Q. J. Roy. Meteor. Soc., 96, 869-886, 2001.

Beekmann, M., Ancellet, G., and Mégie, G.: Climatology of tropospheric ozone in southern Europe and its relation to potential vorticity, J. Geophys. Res., 99, 841-853, 1994.

Bencherif, H., Amraoui, L. E., Sernane, N., Massart, S., Charyulu, D. V., Hauchecorne, A., and Peuch, V.-H.: Examination of the 2002 major warming in the southern hemisphere using groundbased and Odin/SMR assimilated data: stratospheric ozone distributions and tropic/mid-latitude exchange, Can. J. Phys., 85, 1287-1300, 2007.

Bousserez, N., Attié, J.-L., Peuch, V.-H., Michou, M., Pfister, G., Edwards, D., Emmons, L., Mari, C., Barret, B., Arnold, S. R., Heckel, A., Richter, A., Schlager, H., Lewis, A., Avery, M., Sachse, G., Browell, E. V., and Hair, J. W.: Evaluation of the MOCAGE chemistry transport model during the ICARTT/ITOP experiment, J. Geophys. Res., 112, D10S42, doi:10.1029/2006JD007595, 2007.

Browning, K. A.: Evolution of a mesoscale upper tropospheric vorticity maximum and comma cloud from a cloud-free twodimensional potential vorticity anomaly, Q. J. Roy. Meteorol. Soc., 119, 883-906, doi:10.1002/qj.49711951302, 1993. 
Buis, S., Piacentini, A., and Déclat, D.: PALM: a computational framework for assembling high-performance computing applications, Concurrency Computat. Pract. Exper. 18, 231-245, doi:10.1002/cpe.914, 2006.

Courtier, P., Freydier, C., Geleyn, J. F., Rabier, F., and Rochas, M.: The ARPEGE project at Météo France, in: Atmospheric Models, vol.2, 193-231, Workshop on Numerical Methods, Reading, UK, 1991.

Dufour, A., Amodei, M., Ancellet, G., and Peuch, V.-H.: Observed and modelled "chemical weather" during ESCOMPTE, Atmos. Res., 74, 161-189, doi:10.1016/j.atmosres.2004.04.013, 2005.

El Amraoui, L., Peuch, V.-H., Ricaud, P., Massart, S., Semane, N., Teyssèdre, H., Cariolle, D., and Karcher, F.: Ozone loss in the 2002-2003 Arctic vortex deduced from the assimilation of Odin/SMR $\mathrm{O}_{3}$ and $\mathrm{N}_{2} \mathrm{O}$ measurements: $\mathrm{N} 2 \mathrm{O}$ as a dynamical tracer, Q. J. Roy. Meteor. Soc., 134, 217-228, doi:10.1002/qj.191, 2008a.

El Amraoui, L., Semane, N., Peuch, V.-H., and Santee, M. L.: Investigation of dynamical processes in the polar stratospheric vortex during the unusually cold winter 2004/2005, Geophys. Res. Lett., 35, L03803, doi:10.1029/2007GL031251, 2008b.

El Amraoui, L., Attié, J.-L., Semane, N., Claeyman, M., Peuch, V.H., Warner, J., Ricaud, P., Cammas, J.-P., Piacentini, A., Josse, B., Cariolle, D., Massart, S., and Bencherif, H.: Midlatitude stratosphere - troposphere exchange as diagnosed by MLS $\mathrm{O}_{3}$ and MOPITT CO assimilated fields, Atmos. Chem. Phys., 10, 2175-2194, doi:10.5194/acp-10-2175-2010, 2010.

Fisher, M. and Andersson, E.: Developments in 4D-Var and Kalman filtering, in: Technical Memorandum Research Department, vol. 347, ECMWF, Reading, UK, 2001.

Froidevaux, L., Jiang, Y. B., Lambert, A., Livesey, N. J., Read, W. G., Waters, J. W., Browell, E. V., Hair, J. W., Avery, M. A., McGee, T. J., Twigg, L. W., Sumnicht, G. K., Jucks, K. W., Margitan, J. J., Sen, B., Stachnik, R. A., Toon, G. C., Bernath, P. F., Boone, C. D., Walker, K. A., Filipiak, M. J., Harwood, R. S., Fuller, R. A., Manney, G. L., Schwartz, M. J., Daffer, W. H., Drouin, B. J., Cofield, R. E., Cuddy, D. T., Jarnot, R. F., Knosp, B. W., Perun, V. S., Snyder, W. V., Stek, P. C., Thurstans, R. P., and Wagner, P. A.: Validation of Aura Microwave Limb Sounder stratospheric ozone measurements, J. Geophys. Res., 113, D15S20, doi:10.1029/2007JD008771, 2008.

Geer, A. J., Lahoz, W. A., Bekki, S., Bormann, N., Errera, Q., Eskes, H. J., Fonteyn, D., Jackson, D. R., Juckes, M. N., Massart, S., Peuch, V.-H., Rharmili, S., and Segers, A.: The ASSET intercomparison of ozone analyses: method and first results, Atmos. Chem. Phys., 6, 5445-5474, doi:10.5194/acp-6-5445-2006, 2006.

Gouget, H., Vaughan, G., Marenco, A., and Smit, H. G. J.: Decay of a cut-off low and contribution to stratospheretroposphere exchange, J. Geophys. Res., 126, 1117-1141, doi:10.1002/qj.49712656414, 2000.

Hauchecorne, A., Godin, S., Marchand, M., Heese, B., and Souprayen, C.: Quantification of the transport of chemical constituents from the polar vortex to midlatitudes in the lower stratosphere using the high-resolution advection model MIMOSA and effective diffusivity, J. Geophys. Res., 107, 8289, doi:10.1029/2001JD000491, 2002.

Hollingsworth, A., Engelen, R., Textor, C., Boucher, O., Chevallier, F., Dethof, A., Elbern, H., Eskes, H., Flemming, J., Granier, C.,
Kaiser, J. W., Morcrette, J. J., Rayner, P., Peuch, V.-H., Rouill, L., and the GEMS Consortium: Toward a monitoring and forecasting system for atmospheric composition: The GEMS Project, B. Am. Meteorol. Soc., 89, 1147-1164, 2008.

Holton, J. R., Haynes, P. H., McIntyre, M. E., Douglass, A. R., Rood, R. B., and Pfister, L.: Stratosphere-troposphere exchange, Rev. Geophys., 4, 403-439, 1995.

IPCC 1996: IPCC, Climate Change 1995 - The Science of Climate Change, Contribution of Working Group I to the Second Assessment Report, section 2 edited by: Houghton, J. T., Meira Filho, L. G., Callander, B. A., Harris, N., Kattenberg, A., and Maskell, K., University Press, Cambridge, 572 pp., 1996.

Josse, B., Simon, P., and Peuch, V.-H.: Radon global simulation with the multiscale chemistry transport model MOCAGE, Tellus, 56, 339-356, 2004.

Kalnay, E.: Atmospheric modeling, data assimilation, and predictability., University Press, Cambridge, 341 pp., 2003.

Lahoz, W. A., Errera, Q., Swinbank, R., and Fonteyn, D.: Data assimilation of stratospheric constituents: a review, Atmos. Chem. Phys., 7, 5745-5773, doi:10.5194/acp-7-5745-2007, 2007.

Law, K. S., Plantevin, P.-H., Thouret, V., Marenco, A., Asman, W. A. H., Lawrence, M., Crutzen, P. J., Muller, J.-F., Hauglustaine, D. A., and Kanakidou, M.: Comparison between global chemistry transport model results and Measurement of Ozone and Water Vapor by Airbus In-Service Aircraft (MOZAIC) data, J. Geophys. Res., 105, 1503-1525, doi:10.1029/1999JD900474, 2000.

Leblanc, T., Tripathi, O. P., McDermid, I. S., Froidevaux, L., Livesey, N. J., Read, W. G., and Waters, J. W.: Simultaneous lidar and EOS MLS measurements, and modeling, of a rare polar ozone filament event over Mauna Loa Observatory, Hawaii, Geophys. Res. Lett., 33, L16801, doi:10.1029/2006GL026257, 2006.

Lefèvre, F., Brasseur, G. P., Folkins, I., Smith, A. K., and Simon, P.: Chemistry of the 1991-1992 stratospheric winter: three dimensional model simulations, J. Geophys. Res., 99, 8183-8195, 1994.

Louis, J.-F.: Parametric model of vertical eddy fluxes in the atmosphere, Bound. Lay. Meteorol., 17, 187-202, 1979.

Marchand, M., Godin, S., Hauchecorne, A., Lefèvre, F., Bekki, S., and Chipperfield, M.: Influence of polar ozone loss on northern midlatitude regions estimated by a high-resolution chemistry transport model during winter 1999/2000, J. Geophys. Res., 108, 8326, doi:10.1029/2001JD000906, 2003.

Marenco, A., Thouret, V., Nedelec, P., Smit, H. G., Helten, M., Kley, D., Karcher, F., Simon, P., Law, K., Pyle, J., Poschmann, G., Wrede, R. V., Hume, C., and Cook, T.: Measurement of ozone and water vapour by Airbus in-service aircraft: the MOZAIC airborne program, an overview, J. Geophys. Res., 103, 2563125242, 1998.

Massart, S., Piacentini, A., Cariolle, D., El Amraoui, L., and Semane, N.: Assessment of the quality of the ozone measurements from the Odin/SMR instrument using data assimilation, Can. J. Phys., 85, 1209-1223, 2007.

Peuch, V.-H., Amodei, M., Barthet, T., Cathala, M.-L., Michou, M., and Simon, P.: MOCAGE, MOdéle de Chimie Atmosphérique à Grande Echelle, in: Proceedings of Météo France: Workshop on atmospheric modelling, 33-36, Toulouse, France, 1999.

Pisso, I., Real, E., Law, K. S., Legras, B., Bousserez, N., Attie, J. L., and Schlager, H.: Estimation of mixing in the troposphere from Lagrangian trace gas reconstructions during long- 
range pollution plume transport, J. Geophys. Res., 114, D19301, doi:10.1029/2002GL016538, 2009.

Postel, G. A. and Hitchman, H. M.: A climatology of Rossby wave breaking along the subtropical tropopause, J. Atmos. Sci., 56, 359-373, 1999.

Ramaswamy, V., Boucher, O., Haigh, J., Hauglustaine, D., Haywood, J., Myhre, G., Nakajima, T., Shi, G. Y., and Solomon, S.: Radiative Forcing of Climate Change, in: Climate Change 2001: The Scientific Basis. Contribution of working group I to the Third Assessment Report of the Intergovernmental Panel on Climate Change, Cambridge Univ. Press, New York, 349-416, 2001.

Rouïl, L., Honoré, C., Vautard, R., Beekmann, M., Bessagnet, B., Malherbe, L., Meleux, F., Dufour, A., Elichegaray, C., Flaud, J.M., Menut, L., Martin, D., Peuch, A., Peuch, V.-H., and Poisson, N.: An Operational Forecasting and Mapping System for Air Quality in Europe, B. Am. Meteor. Soc., 90, 73-83, 2008.

Semane, N., Peuch, V.-H., Amraoui, L. E., Bencherif, H., Massart, S., Cariolle, D., Attié, J.-L., and Abidab, R.: An observed and analysed stratospheric ozone intrusion over the high Canadian Arctic UTLS region during the summer of 2003, Q. J. Roy. Meteor. Soc., 133, 171-178, doi:10.1002/qj.141, 2007.

Sprenger, M., Wernli, H., and Bourqui, M.: Stratosphere- Troposphere Exchange and Its Relation to Potential Vorticity Streamers and Cutoffs near the Extratropical Tropopause., J. Atmos. Sci., 64, 1587-1602, doi:10.1175/JAS3911.1, 2007.

Stockwell, W. R., Kirchner, F., Khun, M., and Seefeld, S.: A new mechanism for regional atmospheric chemistry modelling, J. Geophys. Res., 102, 25847-25879, 1997.

Stohl, A., Bonasoni, P., Cristofanelli, P., Collins, W., Feichter, J., Frank, A., Forster, C., Gerasopoulos, E., Gäggeler, H., James, P., Kentarchos, T., Kromp-Kolb, H., Krüger, B., Land, C., Meloen, J., Papayannis, A., Priller, A., Seibert, P., Sprenger, M., J. Roelofs, G., E. Scheel, H., Schnabel, C., Siegmund, P., Tobler, L., Trickl, T., Wernli, H., Wirth, V., Zanis, P., and Zerefos, C.: Stratosphere-troposphere exchange: A review, and what we have learned from STACCATO, J. Geophys. Res., 108, 2494-2494, doi:10.1029/2002JD002490, 2003.
Thorncroft, C. D., Hoskins, B. J., and McIntyre, M. E.: Two paradigms of baroclinic-wave life-cycle behaviour, Q. J. Roy. Meteorol. Soc., 119, 17-55, doi:10.1002/qj.49711950903, 1993.

Thouret, V., Marenco, A., Logan, J., Nédélec, P., and Grouhel, C.: Comparisons of ozone measurements from the MOZAIC airborne program and the ozone sounding network at eight locations, J. Geophys. Res., 103, 25695-25720, 1998.

Tripathi, O. P., Leblanc, T., McDermid, I. S., Lefèvre, F., Marchand, M., and Hauchecorne, A.: Forecast, measurement, and modeling of an unprecedented polar ozone filament event over Mauna Loa Observatory, Hawaii, J. Geophys. Res., 111, D20308, doi:10.1029/2006JD007177, 2006.

Wargan, K., Pawson, S., Stajner, I., and Thouret, V.: Spatial structure of assimilated ozone in the upper troposphere and lower stratosphere, J. Geophys. Res., 115, D24316, doi:10.1029/2010JD013941, 2010.

Waters, J. W., Froidevaux, L., Harwood, R. S., Jarnot, R. F., Pickett, H. M., Read, W. G., Siegel, P. H., Cofield, R. E., Filipiak, M. J., Flower, D. A., Holden, J. R., Lau, G. K. K., Livesey, N. J., Manney, G. L., Pumphrey, H. C., Santee, M. L., Wu, D. L., Cuddy, D. T., Lay, R. R., Loo, M. S., Perun, V. S., Schwartz, M. J., Stek, P. C., Thurstans, R. P., Boyles, M. A., Chandra, K. M., Chavez, M. C., Chen, G. S., Chudasama, B. V., Dodge, R., Fuller, R. A., Girard, M. A., Jiang, J. H., Jiang, Y. B., Knosp, B. W., LaBelle, R. C., Lam, J. C., Lee, K. A., Miller, D., Oswald, J. E., Patel, N. C., Pukala, D. M., Quintero, O., Scaff, D. M., Snyder, W. V., Tope, M. C., Wagner, P. A., and Walch, M. J.: The Earth Observing System Microwave Limb Sounder (EOS MLS) on the Aura satellite, IEEE T. Geosci. Remote Sens., 44, 1075-7092, 2006.

Wernli, H. and Sprenger, M.: Identification and ERA-15 Climatology of Potential Vorticity Streamers and Cutoffs near the Extratropical Tropopause., J. Atmos. Sci., 64, 1569-1586, doi:10.1175/JAS3912.1, 2007.

World Meteorological Organization: Atmospheric Ozone: 1985, Global ozone research and monitoring project report no. 16, 1986. 